\title{
Articles
}

\section{Same-Sex Marriage, Conflict of Laws, and the Unconstitutional Public Policy Exception}

\author{
Larry Kramer ${ }^{\dagger}$
}

It finally happened. On Tuesday, December 3, 1996, a Honolulu judge struck down a Hawaiian law permitting only opposite-sex couples to marry, and Hawaii became the first state to recognize same-sex marriages.' Of course, the ruling hardly came as a surprise. The surprise had come three years earlier, when the Hawaii Supreme Court ruled in Baehr v. Lewin that a restriction on same-sex marriage constituted sex discrimination under the state constitution and remanded to give the state an opportunity to show that its law served a compelling interest. Still, the trial court's finding that it did not brings a further degree of closure to one chapter in the same-sex marriage controversy: We can confidently predict that Hawaii will recognize same-sex marriages, for while the trial court stayed its mandate pending appeal, it is very unlikely that the decision will be overturned.

Now that a state has made same-sex marriages legal, the battleground for gay and lesbian couples shifts to other states-eventually, perhaps, to persuade these states to follow Hawaii's lead; in the meantime, to get them to recognize the validity of same-sex marriages performed in Hawaii. But opponents of legally recognized marriages between same-sex partners have not been quiescent. On the contrary, horrified by the prospect that gay and lesbian couples might be able to marry in Hawaii and force other states to recognize their union fully and for all purposes, adversaries of same-sex marriage began a campaign to limit the effect of Hawaiian law almost as soon as Baehr was

$\dagger$ Professor of Law, New York University Law School (i.c., not that Larry Kramer). I am grateful to Mary Anne Case, Sarah Coyne, David Currie, Jack Goldsmith. Herma Hill Kay, Doug Laycock, Rachel Moran, William Richman, David Shapiro, Linda Silberman, Louise Weinberg. Russell Weinuraub, and Tobias Wolff for their suggestions. This piece was originally presented at a conference held at the Quinnipiac College School of Law, the proceedings of which will be published in Volume 16 of the Quinnipiac Law Review. Material in note 136 is reprinted with permission of the Fordhan Law Review.

1. See Baehr v. Miike, CIV. No. 91-1394, 1996 WL 694235 (Haw. Cir. C. Dec. 3. 1996)

2. 852 P.2d 44 (Haw. 1993). 
decided. Efforts were made to persuade state legislatures to adopt statutes explicitly declaring that same-sex marriages violate public policy and are void. These efforts succeeded in a number of states. ${ }^{3}$

The popular media raised questions about whether such laws were permissible or whether states would be required as a matter of full faith and credit to recognize marriages celebrated lawfully in Hawaii. ${ }^{4}$ So opponents of gay and lesbian marriage went to Congress. They found a receptive audience, and Congress soon enacted the ironically named "Defense of Marriage Act" (DOMA), which permits states to refuse recognition to "any public act, record, or judicial proceeding of any other State ... respecting a relationship between persons of the same sex that is treated as a marriage under the laws of such other State."

As same-sex couples begin making plans to get married in Hawaii, and as other states begin gearing up to deny their marriages any effect, some important questions arise. First, assuming that states are not required to permit same-sex marriage under their own laws, to what extent does the federal Constitution obligate them nevertheless to recognize such marriages if validly performed in Hawaii? Second, assuming that states sometimes are obligated to recognize Hawaiian marriages, can Congress relieve them of the obligation? As we will see, both questions are more complicated than partisans on either side of the issue seem to have realized.

Part I of this Article describes existing law. The traditional, and still usual, rule for interstate marriages is to uphold the validity of a marriage valid where it was celebrated. This "place of celebration" rule is then subject to a number of exceptions, most of which are narrowly construed. The vast majority of cases in which an exception is made are based on "public policy," among the hoariest of hoary conflicts doctrines. The availability of this exception appears to make DOMA unnecessary by making potential same-sex marriage problems easy from a conflict-of-laws perspective.

That is true, however, only if one accepts the law that allows states to make this exception. Part II, the heart of the Article, argues that the public policy doctrine ought to be deemed unconstitutional-not just in same-sex marriage cases, mind you, but across the board. ${ }^{6}$ The argument, in a nutshell,

3. See, e.g., ARIZ. REv. STAT. ANN. § 25-101(C) (West Supp. 1996); ConN. Gen. STAT. ANN. § 46a81r (West 1995); DEL. Code ANN. tit. 13, § 101(a) (Supp. 1996); 750 ILl. CoMP. STAT. ANN. 5/213.1 (West, Westlaw through 1996 Act 89-679); LA. Crv. CODE ANN, art. 96 (West 1993); S.C. CODB ANN. $\$$ 20-1-15 (Law Co-op. Supp. 1996); UTAH CODE ANN. § 30-1-2 (1995); VA. CODE ANN. § 20-45.2 (Michic 1995).

4. See, e.g., Carey Goldberg, Couple Who Stirred Issue of Same-Sex Marriage Still Hopeful, N.Y. TMES, July 28, 1996, at A12; Melissa Healy, Senate OKs Bill Against Same-Sex Marriages, L.A. TimeS, Sept. 11, 1996, at A1; John E. Yang, Senate Passes Bill Against Same-Sex Marriage, WASH. Post, Scpt. 11, 1996, at A1.

5. Defense of Marriage Act, Pub. L. No. 104-199, § 2(a), 1996 U.S.C.C.A.N. (110 Stat.) 2419, 2419 (to be codified at 1 U.S.C. $\S 7$ ).

6. There may be other potential sources of constitutional protection for gay and lesbian couples who 
is that the Full Faith and Credit Clause prohibits states from selectively discriminating in choice of law based on judgments about the desirability or obnoxiousness of other states' policies. However much sense this exception makes in international law, where a case for it can still be made, it has no place in the American federal system.

Part II goes on to examine the implications of this understanding of full faith and credit for choice of law generally and for marriage in particular. These are significant, but hardly calamitous. For apart from "better law" analysis-which permits courts to choose among conflicting laws by picking the one deemed to reflect more enlightened policy, and which. I conclude, should also be found unconstitutional-modern approaches to choice of law are all carefully structured to avoid inquiries about whose law is preferable or superior as a substantive matter. Most choice-of-law doctrine would thus remain unaffected.

What my argument means for marriage law in particular depends on how states respond to this new constitutional regime. If the argument in Par II is right, states will find it difficult to refuse recognition to same-sex marriages celebrated lawfully in Hawaii without altering their existing choice-of-law rules for marriage generally. They will not lose the ability to adopt and enforce rules respecting which marriages are valid and which are not; Hawaii cannot, after all, dictate marriage law to the rest of the nation. They will, however, lose their ability to single out Hawaii law for nonrecognition through use of the public policy exception. Some states may respond by extending the place of celebration rule even to same-sex marriages celebrated in Hawaii. Others, however, may choose to adopt an alternative approach to choice of law: perhaps one of the modern approaches, like interest analysis, the Second Restatement, or comparative impairment. This is perfectly acceptable even though it may result in denying recognition to some same-sex marriages celebrated in Hawaii. The only limitation proposed here is that, whatever choice-of-law rule or approach a state adopts, it cannot alter its willingness to apply foreign law based solely on the substantive policy of the other state.

\footnotetext{
want to marry, but they probably do not offer much hope of success at the present tume The Cuun's recent decision in Romer v. Evans, 116 S. Ct. 1620 (1996), stnking down on equal protection grounds a provision of the Colorado constitution that prohibited state and local legislatures from offenng "spectal" protection to gays and lesbians, came as something of a surprise. I suspect that Jusuce Kennedy followed his unusual line of reasoning in the case precisely because the Cour is not yet prepared generally to ratse the level of scrutiny given to laws that discriminate on the basis of sexual onentation In the meanume, Bowers $v$ Hardwick, 478 U.S. 186 (1986), stands as implacably as ever in the way of durect substantuve protection And neither the Privileges and Immunities Clause nor the nght to travel offer much upon whith to build an argument. A Note in the Stanford Law Review tries hard to construct a plausible argument based on these rights but still concludes that it is unlikely to succeed. See Thomas M1. Keane, Note, Aloha, Marriage? Constitutional and Choice of Law'Arguments for Recognnon of Same-Sex.Harriages. +7 STA.V L. REV. 499, 508-10 (1995). Indeed, the author must stretch even to make the case look plausible. at least in situations where a nonresident couple travels to Hawaii solely to evade the marnage restnctions of their home state.
} 
A state cannot do this, that is, unless Congress has the power to make an exception to full faith and credit and to authorize states to refuse recognition to same-sex marriages. Hence, DOMA may not be supererogatory after all. Part III therefore examines Congress's power to prescribe choice-of-law rules for states. Under the Effects Clause of Article IV, Congress is entitled to define how each state's law shall be treated by other states. It might follow that Congress can permit states to deny recognition to same-sex marriages on public policy grounds, in which case DOMA ends any remaining legal controversy (politics is another matter). But the limits of congressional power under the Effects Clause have never been examined, in part because Congress has never tested them. And the better interpretation is that Congress's power to create choice-of-law rules is not unlimited-federal authorities have no more business authorizing a public policy exception than do states. DOMA is unconstitutional.

\section{EXISTING DOCTRINE}

\section{A. Choice of Law}

Before proceeding further, we need to understand the basic rules governing choice of law in marriage cases. To recapitulate the law in this area fully would take some time; no surprise really, since nothing in conflicts law is ever neat or tidy. There are just too many states making independent decisions and too many different variations of each problem to consider. For present purposes, we can work with the following paradigmatic situation: $A$ and $B$ live in state $X$, which does not recognize their right to marry; they travel to Hawaii to get married, and immediately after the ceremony return home to resume their lives together. How would state $X$ view their marriage? ${ }^{8}$

7. For more detailed summaries than mine, see ROBERT A. LEFLAR ET AL., AMERICAN CONFLICTS LAW ch. 23 (4th ed. Michie Co. 1986) (1959); Eugene F. SCOLES \& PETER HAY, Conflict of LAWS ch. 13 (2d ed. 1992); Deborah M. Henson, Will Same-Sex Marriages Be Recognized in Sister States?: Full Faith and Credit and Due Process Limitations on States' Choice of Law Regarding the Status and Incidents of Homosexual Marriages Following Hawaii's Baehr v. Lewin, 32 U. LOUISViLlE J. FAM. L. 551, 560-76 (1993-94); Joseph W. Hovermill, A Conflict of Laws and Morals: The Choice of Law Implications of Hawaii's Recognition of Same-Sex Marriages, 53 MD. L. REV, 450, 454-66 (1994); Candice L. Sage, Note, Sister-State Recognition of Valid Same-Sex Marriages; Baehr v. Lewin-How Will It Play in Peoria?, 28 IND. L. REV. 115 (1994).

8. This sort of "weekend marriage" presents the weakest case for applying Hawail law to determine the validity of a marriage. Other cases can easily be imagined in which Hawaii's claim to have its law govern would be stronger: longtime Hawaii residents may move to state $X$; one of the spouses may dic, leaving property in $X$; or one of the spouses could move to $X$ without getting a divorce, leaving doubts as to marital status. In each of these cases, Hawaii's interest in having its law determine marital status is stronger than in the case where Hawaii's only contact is that $X$ 's residents were married in Hawail. I want to work with this case, however, both because it is the hardest one and because it will be by far the most common. 
As a general matter, every state recognizes the validity of a marriage valid where it was celebrated (i.e., where the marriage contract was made). 'The place of celebration rule is not, of course, carved in stone or revealed from heaven. States do not have to follow it, and nothing in the Constitution precludes them from adopting a different rule (say, for example, applying the law where either or both of the parties are domiciled when they get married). A variety of considerations-in particular, widely shared policies that favor validating marriages consummated in good faith and enabling partners to know with certainty whether their marriage is valid-have led states to conclude that the best rule is one recognizing marriages legal where they were celebrated. This has long been the rule in every state of the United States, ${ }^{10}$ and it continues to govern pretty much without regard for whether a state adheres to the traditional jurisdiction-selecting rules or opts for one of the fancier modem approaches."

Its general convenience notwithstanding, every state recognizes situations in which it abandons the place of celebration rule. Many states, for example, will recognize a marriage that is invalid in the state where it was celebrated if it is valid where the parties are domiciled. ${ }^{12}$ Conversely, some states will refuse to recognize a marriage that is valid where it was celebrated if the partners went there solely to evade restrictions imposed in their domicile. ${ }^{13}$ Surprisingly, this entirely reasonable exception is rarely used, ${ }^{14}$ and its

9. See 2 RESTATEMENT (SECOND) OF CONFLICT OF LAWS $\$ 283$ (1971): SCOLES \& HaY. supra notc $7, \S 13.5$.

10. See Restatement of the Law of CONFlict of Laws $\S 121$ (1934). Joseph Story. COMMENTARIES ON THE CONFICT OF LAWS $\$ 113$ (8th od. Boston, Liulc, Brown \& Co 1883).

11. See Barbara J. Cox, Same-Sex Marriage and Choice-of-Law: If We Mam in Hawan, Are We Sull Married When We Return Home?, 1994 WIS. L. REV. 1033. 1097-98; cf. SCOLEs \& HaY. supra nole 7. $\$ 13.2$, at 433 (stating that law of state where marriage was celebraled will govern where such law conflicts with law of state of domicile if expectations of parties to mariage would be thwarted under law of domiciliary state). Traditional and modem approaches to choice of law are detailed infra notes 105-12 and accompanying text.

12. See, e.g., SCOLES \& HAY, supra note 7, § 13.5, at 437. More than 20 stales have adopted this rulc by legislation. Seven have done so by enacting the Uniform Marriage and Divorce Act, which provides that marriages are valid if "valid at the time of the contract or subsequendy validated by the laws of the place in which they were contracted or by the domicil of the parties." UNIF. MARRLAGE AND DNORCE ACT $\S$ 210, 9A U.L.A. 176 (1987). Fourteen other states have drafted their own validaung legislation. See Cox. supra note 11, at 1066-68 nn.185-208 (citing statutes); Keane, supro note 6, at $515 \mathrm{n} .103$ (same).

13. See SCOLES \& HAY, supra note 7, § 13.2, at 432; id. \$ 13.14. at 453-54; RUSSELL J WENTRAUB, COMMENTARY ON THE CONFLICT OF LAWS \$ 5.1C, al 234 (3d ed. 1986). The National Conference of Commissioners on Uniform Laws adopted a proposal to this effect in 1912 but withdrew 11 in 1943 The Uniform Marriage Evasion Act is still on the books in four states that adopted it, however. See Cox, supra note 11 , at 1074 . Ilinois is in the unique position of having adopted both marriage evasion and mamage validation legislation. See id. at 1073.

14. See SCOLES \& HAY, supra note $7, \S 13.2$, al 432; id. \$1314, at 454: WentrauB, supra note 13. § 5.1C, at 234. Compare, e.g., Wilkins v. Zelichowski, 140 A.2d 65 (N.J. 1958) (applying domiculary law to annul marriage on ground that bride was underage in action brought by her soon after mamage). with State v. Graves, 307 S.W.2d 545 (Ark. 1957) (refusing to apply domiciliary law to charges of coninbutung to delinquency of minor brought against parents by state soon after mamage), and In re May's Estafe. 114 N.E.2d 4 (N.Y. 1953) (refusing to allow child to preclude father from appoinument as executor of mother's estate by showing that marriage of 32 years was invalid in domicilary state). 
appearance often depends on how quickly a marriage is challenged and whether the challenger is one of the partners or some other interested party. Even where the rule against deliberate evasion is codified, courts have construed it narrowly and found ways to uphold most marriages. ${ }^{15}$

By far the most common exception to the place of celebration rule is for marriages deemed contrary to the forum's strong public policy, and this again seems to be true regardless of how a state generally handles its choice-of-law problems. ${ }^{16}$ Of course, public policy is not violated every time the forum's law differs from that of the place of celebration; otherwise, the exception would swallow the rule. Rather, as in other contexts where "public policy" is used to avoid a conflicts rule, the exception applies (in Judge Cardozo's wellknown formulation) only where another state's law violates "some fundamental principle of justice, some prevalent conception of good morals, some deeprooted tradition of the common weal."17 Although invocation of the public policy exception varies somewhat from state to state, a number of common situations are found in marriage law. Typically, states turn to public policy in connection with issues like incest, polygamy, marriage by minors, and the length of any waiting period required before remarrying after a divorce. ${ }^{18}$

Two refinements should be noted in how the public policy doctrine is used in marriage cases. First, the exception is not employed as an overly blunt tool, but is selectively refined in application. Rather than repudiate the place of celebration rule in every case that would be incest under forum law, courts in many states recognize that some differences are more matters of degree than of fundamental policy. ${ }^{19} \mathrm{~A}$ state that permits second cousins to marry may be more willing to recognize a law extending the privilege to first cousins than one extending it to siblings; a state that permits sixteen-year-olds to marry may apply another state's law permitting fifteen-year-olds to do so, but not one extending the right to nine-year-olds. States may also be more likely to ignore public policy considerations for couples with legitimate expectation interests: There is an obvious difference between a couple that recently married outside a state to evade that state's marriage restrictions and a couple that moved into the state after living together for twenty years in a place that recognized their union. ${ }^{20}$

15. See Cox, supra note 11 , at $1074-82$.

16. See 2 RESTATEMENT (SECOND) OF CONFLICT OF LAWS $\$ 283 \mathrm{cmt} . \mathrm{k}$ (1971); WEINTRAUB, supra note 13, § 5.1A, at 230-31; Cox, supra note 11, at 1098; Henson, supra note 7, at 562-76; Hovermill, supra note 7, at 455-66; Sage, supra note 7, at 118-20.

17. Loucks v. Standard Oil Co., 120 N.E. 198, 202 (N.Y. 1918). Weintraub calls Cardozo's formulation in Loucks "[t]he classic definition of public policy as a valid reason for closing the forum to suit." WEINTRAUB, supra note $13, \S 3.6$, at 84 .

18. See treatises cited supra note 7.

19. See SCOLES \& HAY, supra note $7, \S \S 13.11-.12$.

20. See In re May's Estate, 114 N.E.2d 4, 6 (N.Y. 1953); Willis L.M. Reese, Marriage in American Confict of Laws, 26 INT'L \& COMP. L.Q. 952, 960 (1977). 
Second, many states distinguish between the validity of a marriage and the ability to enjoy its "incidents." There was a time when courts treated marriage as a simple yes-or-no, up-or-down proposition: A marriage was either valid, in which case it was valid for all purposes, or it was not, in which case it was invalid for all purposes. Particularly in this century, however, judges have been willing to draw finer lines, applying the place of celebration rule to the question of validity while saving the public policy exception for particular "incidents" of being married. ${ }^{21}$ The right to cohabit, for example, is a usual incident of being married, but not a necessary one. A man married to two wives in India might be able to move to Kansas without being prosecuted for bigamy, but Kansas might forbid the three of them from living together." Al the same time, the surviving wives might both be permitted to inherit as spouses under the state's law of succession. ${ }^{23}$

Two relevant generalizations can be made about choice of law in marriage cases. First, the place of celebration rule governs the vast majority of cases. Exceptions exist, but these are used with considerable reluctance, even when embodied in statutes. Second, of the small subset of cases in which the place of celebration rule is not applied, the vast majority are decided on public policy grounds. Other exceptions exist, but these are seldom invoked and typically appear in conjunction with a public policy objection. A state may, for example, allow parties to marry elsewhere solely to evade its restrictive law unless they do so to get the benefit of a law deemed contrary to the forum's strong public policy. As same-sex marriages become an issue, then, we can expect reluctant states to turn to the public policy doctrine to protect their interests.

\section{B. The Public Policy Doctrine}

Given its likely role at the heart of any future controversy over same-sex marriages, I want to examine the public policy doctrine a bit more closely. A public policy exception in some form is recognized in every state of the United States and has always been part of conflict-of-laws analysis in this country. ${ }^{22}$

21. See 2 RESTATEMENT (SECOND) OF CONFLICT OF LAWS $\$ 284 \mathrm{cmt}$ c (1971); Hovermill, supra nole 7 , at $465-66$.

22. See LEFLAR ET AL., supra note 7, $\$ 219$, at 604 \& n.5 (citing cases)

23. See In re Dalip Singh Bir's Estate, 188 P.2d 499. 501 (Cal. Dist. C. App. 1948); Mttler v. Lucks, 36 So. 2d 140, 141-42 (Miss. 1948); In re Estale of Lenherr, 314 A.2d 255, 259 (Pa. 1974); 2 RESTATEMENT (SECOND) OF CONFLICT OF LAWS $\$ 284 \mathrm{~cm}$ ts. c-d (1971); WENTRAUB, supra note 13. $\$$ 5.1B.

24. Useful discussions of the public policy doctrine can be found in any conflict-of-laws treause. A brief analysis of its origin and history can be found in FRIEDRICH K. JUENGER. CHOICE OF LAW AND Multistate Justice 79-81 (1993), or HenRI BatifFol \& Paul Lagarde. I Drott international. PRIVE 91 354-55 (7th ed. 1981). Classic treatments that are sull valuable include Emest G. Lorenzen. Territoriality, Public Policy and the Conflict of Laws, 33 Y ALE L.J. 736 (1924); Anthur Nussbaum. Public Policy and the Political Crisis in the Conflict of Laws. 49 YALE L.J. 1027 (1940): and Monrad G. Paulsen \& Michael I. Sovern, "Public Policy" in the Conflict of Lass. 56 COLUM. L. REv 969 (1956). 
It actually developed earlier, as a matter of customary international law, and was incorporated into American practice with no particular thought given to its appropriateness in the context of a federal system defined by a written constitution. ${ }^{25}$ "Public policy" functions as an escape from the usual conflicts rules: Content with its choice-of-law rules in most cases, a court may on occasion find itself asked to apply a law significantly at odds with forum notions of justice or good policy. In such cases, the court can use the public policy doctrine to make an exception, refusing to apply the undesirable law. The basic idea is captured nicely in Judge Cardozo's description in Loucks $v$. Standard Oil Co. ${ }^{26}$ a fragment of which was already quoted above:

The courts are not free to refuse to enforce a foreign right at the pleasure of the judges, to suit the individual notion of expediency or fairness. They do not close their doors, unless help would violate some fundamental principle of justice, some prevalent conception of good morals, some deep-rooted tradition of the common weal. ${ }^{27}$

I want to highlight four aspects of the public policy doctrine here. ${ }^{28}$ First, in conflict of laws the phrase "public policy" normally refers to judge-made exceptions to a state's choice-of-law rules and does not include exceptions created by statute. But the essence of the public policy doctrine, plainly expressed in Cardozo's language, is that the law of another state need not be recognized if it too deeply offends forum standards. It is, in other words, a content-based principle. That being so, I see no reason to limit the doctrine to judicial decisions, and in this Article I will use the term "public policy" to refer to any decision, whether by statute or common law, to make an exception to otherwise applicable choice-of-law rules when those rules select a law embracing disfavored policy. After all, it makes absolutely no difference from the perspective of either the parties or other states whether the decision that some law is too offensive to apply comes from a state's courts or from its legislature. Statutes directing courts not to follow the place of celebration rule if this means recognizing marriages the forum deems incestuous, polygamous, or otherwise undesirable are, for all relevant purposes, identical to judicial decisions reaching the same result.

Second, if courts took Judge Cardozo's language in Loucks seriously, the public policy exception would be very narrow and relatively unimportant. At

25. See Douglas Laycock, Equal Citizens of Equal and Territorial States: The Constitutional Foundations of Choice of Law, 92 COLUM. L. REV. 249, 313 (1992). For example, see STORY, supra note 10 , the seminal text organizing the modem field of conflict of laws, which treats international and interstate cases and problems interchangeably.

26. 120 N.E. 198 (N.Y. 1918).

27. Id. at 202.

28. The justification for this exception is examined in greater detail below. See infra notes 92-101 and accompanying text. For the moment, I want only to describe its basic operation in practice. 
least among states of the United States, very few laws that are also constitutional can fairly be characterized as violating "fundamental principles of justice." Problems like segregation and abortion, and maybe even same-sex marriage, reflect differences on this order, but little else. Yet while the public policy exception has been relatively confined in the marriage cases, it is invoked far more frequently in other contexts, and in much more dubious circumstances. Is the Loucks test truly satisfied by laws setting damages caps $?^{29}$ Authorizing direct actions against insurers? $?^{30}$ Permitting spouses to sue one another in tort? ${ }^{31}$ Barring guests from doing so $?^{32}$ Enforcing a noncompetition agreement ? $^{33}$ Permitting insurance proceeds to be set off against tort damages? ${ }^{34}$ One could go on endlessly citing examples like these, but the point seems clear enough: Courts have broad discretion to use the public policy doctrine, and they have exercised it to lower the threshold of what violates public policy to a considerable degree. It is tempting to dismiss these (and a thousand other) decisions as abuses, but at some point an "abuse" becomes so widespread that we must acknowledge it as the rule. So it is (and has been for some time since Loucks was decided) with respect to both the lowered threshold for invoking the public policy doctrine and the broad discretion implicit in its use. Many commentators, myself included, dislike the exception for precisely this reason. But it remains popular with judges. ${ }^{35}$

Third, in its traditional formulation, courts that used the public policy doctrine would dismiss on jurisdictional grounds. This makes sense given the explanation for making an exception: Forum choice-of-law rules direct the court to apply another state's law that the court is reluctant to recognize

29. See Kilberg v. Northeast Airlines, Inc., 172 N.E.2d 526, 529 (N.Y. 1961) (holding that New York public policy considerations allowed plaintiff to recover damages in excess of Massachusetus statutory limit).

30. See Marchlik v. Coronet Ins. Co., 239 N.E.2d 799. 802-03 (Ill. 1968) (holding that Hlunots public policy barred direet suits against insurers and, therefore. Ilinois cours could not be forum for cases brought under Wisconsin direct action statutes).

31. See Mertz v. Merz, 3 N.E.2d 597. 598-600 (N.Y. 1936) (holding that New York public poltcy precluded any tort liability between spouses stemming from Connecticut law).

32. See Owen v. Owen, 444 N.W.2d 710.713 (S.D. 1989) (holding that wife could sue husband under favorable South Dakota guest statute because foreign state's guest statute contradieted South Dakota public policy).

33. See DeSantis v. Wackenhut Corp., 793 S.W.2d 670. 678-79 (Tex. 1990) (holding that Texas rather than Florida law applied to enforceability of noncompetition agreement, whose terms expressly chose Florida law as governing agreement, because of Texas public policy concems)

34. See Moore v. Subaru of America, 891 F.2d 1445, 1449-50 (10uh Cir 1989) (holding that Oklahoma law requiring setoffs applied despite parties' contractual choice of Indrana law) As a technical matter, Moore and DeSantis were cases involving the scope of party autonomy in contract and rested on the "fundamental policy" exception of 1 RESTATEMENT (SECOND) OF CONFLICT OF LAwS \& 187(2)(b) (1971). But while the Restatement suggests that its test of "fundamentality" is less stringent than the common law public policy exception, see id. $\$ 187(2)(b) \mathrm{cmt}$. g. in practice the two exceptions are treated as interchangeable.

35. The charge of arbitrariness is to some extent answered (though not enturely eliminated) if the decision to make an exception on public policy grounds is embodiod in a statutc. as is true in a number of states with respect to same-sex marriages. See supra note 3 . But statutes of this son are rare tn other contexts, and most states have declined to adopt them even in connection with same-sex mamage. 
because of its content. That fact does not make forum law more applicable, however, so the court simply declines to exercise jurisdiction-leaving the parties free to enforce their rights in some less offended forum. This is clearly how Judge Cardozo thought the exception worked in Loucks. Today, however, courts that rely on public policy seldom stop at the jurisdictional threshold, but rather make the occasion an excuse to apply forum law. ${ }^{36}$ This is invariably true in the marriage cases; rather than merely refuse to apply the place of celebration rule, courts routinely apply forum law and declare the suspect marriages invalid. ${ }^{37}$

Finally, although courts do not say so, the extent and nature of the contacts between the parties, the litigation, and the forum plainly bear on whether the public policy exception is applied. Calling this "the 'relativity' of public policy," Professor Arthur Nussbaum explains:

In general, however, a foreign law which in itself is repugnant to the forum will be accorded recognition where the repercussion of that law upon the forum is remote and unharmful. Although the forum abhors polygamy, it will, nevertheless, recognize the legitimacy of a child born abroad in a polygamous marriage entered into and valid abroad. All depends on the circumstances, or, more precisely, on the importance of the "contacts" of the case with the territory of the forum. ${ }^{38}$

I like to illustrate this point to students by asking them to compare two cases decided within two years by a New York court whose membership underwent no significant changes: Mertz v. Mertz, ${ }^{39}$ and Holzer v. Deutsche ReichsbahnGesellschaft. ${ }^{40}$ In Mertz, the court found that a Connecticut law permitting spouses to sue one another was contrary to New York public policy; ${ }^{41}$ in Holzer, the court ruled that Hitler's Nuremberg laws were not. ${ }^{42}$ I think it safe to say the difference is not that Connecticut's decision to lift interspousal immunity violated "some fundamental principle of justice, some prevalent conception of good morals," whereas Germany's decision to bar non-Aryans from working or being paid did not. But Mertz involved a husband and wife from New York injured while driving in Connecticut, while Holzer was brought by a German citizen against his German employer. In neither case does the court rely on this consideration, but it seems fair to assume that it was nonetheless significant. ${ }^{43}$

\footnotetext{
36. See, e.g., cases cited supra notes 29-34.

37. See, e.g., Owen, 444 N.W.2d at 713.

38. Nussbaum, supra note 24 , at 1030-31 (footnotes omitted).

39. 3 N.E.2d 597 (N.Y. 1936).

40. 14 N.E.2d 798 (N.Y. 1938).

41. See Mertz, 3 N.E.2d at 600.

42. See Holzer, 14 N.E.2d at 800 .

43. It may still seem difficult to read about Holzer without reacting cynically to the court's failure to
} 
Most conflicts scholars explain this "relativity" principle as a tool judges use to mask their preference for a policy-based approach to conflict of laws. Faced with a case in which there are significant forum contacts, but unwilling openly to abandon a choice-of-law rule that makes these contacts irrelevant, the court invokes public policy to reach a more desirable outcome. In this imagining, the public policy exception is driven less by the offensiveness of foreign law than by the arbitrariness of traditional choice-of-law rules. Hence, as Monrad Paulsen and Michael Sovern conclude, "[t]he common invocation of the public policy argument to defeat a foreign claim is a denial that foreign law should govern at all and an assertion of the forum's right to have its law applied to the transaction because of the forum's relationship to it." wh

Whether true or not as a description of underlying judicial motives, the fact remains that the public policy doctrine operates selectively based on the content of foreign law. The forum may choose to abandon its ordinary rule in some cases where forum contacts are strong, but departures are limited to a subset of such cases in which the otherwise applicable foreign law is, in addition, deemed offensive. In the marriage context, for example, states have not used public policy surreptitiously to replace the place of celebration rule with a rule that turns on the couple's domicile. Rather, the forum continues to recognize the marriages of forum residents celebrated elsewhere-except where the marriage in question is deemed particularly objectionable. In other words, invocation of the public policy exception may sometimes reflect increased forum concern based on the strength of the forum's contacts, but the increased concern remains a reaction to the content of the foreign law that would otherwise apply.

With these premises in mind, we can predict the likely operation of the public policy doctrine in same-sex marriage cases. With or without explicit authorization from Congress or state legislatures, couns are relatively free to make an exception to the place of celebration rule for same-sex marriages. They are most likely to do so, moreover, in cases like my initial hypothetical, in which a couple travels to Hawaii to get married with no intention of changing domiciles. If applied, the exception almost certainly will lead to a

invoke the public policy exception: Apan from laws permitting slavery or apartheid. it is hard to think of examples where the doctrine seems so appropriate. In faumess to the judges. there was a further complication. Holzer was seeking damages for breach of contract as a result of being fired. and his employer defended on the ground that German law left the employer no chotce but to discharge hum. To apply the public policy doctrine thus meant permitting Holzer to bring his clam for damages whule denying the defendant its only viable defense. In Bradford Electric Light Co. v. Clapper. 286 U S 145. 160 (1932), the Supreme Coun held that, when public policy is raised to bas a defense rather than a clam. faumess requires the court either to deny the request or to dismiss the whole case for lack of junsdiction. In Holzer. the coun chose the first alternative. It did not leave Holzer remediless, however, for $1 \mathrm{l}$ went on to hold that language in the employment contract requiring compensation in the event Holzer became "unable to work" could be interpreted to include causes other than physical disibility, like being placed in detention. Concluding that this made it inappropriate to dismiss at the pleading stage, the court remanded for further proceedings. See Holzer, 14 N.E.2d at $800-01$.

44. Paulsen \& Sovern, supra note 24, at 981 
declaration that such marriages are invalid.

It is possible that some courts could choose not to classify same-sex marriages as contrary to their states' public policy, which may explain why conservatives in so many states are lobbying to have the principle codified. Advocates of gay and lesbian rights have been surprisingly successful in blocking these efforts, though a number of states have adopted legislation explicitly declaring same-sex marriages void or contrary to public policy. ${ }^{45}$ These victories merely leave the issue open for judicial resolution, however. And while a number of commentators have argued that public policy does not require a state to invalidate same-sex marriages, ${ }^{46}$ I suspect that such marriages will continue to be disapproved in most states for at least the foreseeable future. Given the discretion and flexibility inherent in the public policy doctrine, arguments that it is not always applied in similar or even "worse" situations probably will not matter much. The simple fact is that the public policy exception is readily available for use in nullifying same-sex marriages performed in Hawaii, and it is probably naive not to expect states to use it.

\section{FULL FAITH AND CREDIT}

Is that all, then? Both popular and academic commentators seem to think that the Constitution should have something to say about the matter. They point in particular to the Full Faith and Credit Clause, which looks on its face as if it were written for precisely this sort of problem. ${ }^{47}$ As presently interpreted, however, this Clause requires a forum to apply another state's law only if the forum state lacks significant contacts with the parties or litigation. ${ }^{48}$ The Full Faith and Credit Clause does not, in other words, require a state to defer to the place of celebration if that state is (for example) the domicile of either or both of the married parties.

\section{A. Some Basic Doctrine}

It is probably worth taking a moment to explain this interpretation, which at a glance could be thought to contradict the plain language of the Full Faith

45. See, e.g., statutes cited supra note 3.

46. See Cox, supra note 11, at 1099-117; Henson, supra note 7, at 576-81; Hovermill, supra note 7, at 481-92; Keane, supra note 6, at 516-28; Note, In Sickness and in Health, in Hawaii and Where Else?: Conflict of Laws and Recognition of Same-Sex Marriages, 109 HARV. L. REV. 2038, 2045-50 (1996); cf. Jennifer Gerarda Brown, Competitive Federalism and the Legislative Incentives to Recognize Same-Sex Marriages, 68 S. CAL. L. REv. 745, 788-93 (1995) (noting arguments for limiting public policy exception).

47. See U.S. CONST. art. IV, \& 1 ("Full Faith and Credit shall be given in each State to the public Acts . . . of every other State."). As noted above, supra note 6, there are other arguments that can be made to support the unconstitutionality of restricting same-sex marriage, but these seem unlikely to succed.

48. See Phillips Petroleum Co. v. Shutts, 472 U.S. 797, 818-19, 821-22 (1985); Allstate Ins. Co. v. Hague, 449 U.S. 302, 308 (1981). 
and Credit Clause. No one paid much attention to the problem of faith and credit to laws (as opposed to judgments) until well into the twentieth century. Because every state followed basically the same choice-of-law rules, there was little disagreement about whose law governed particular cases. Problems arose, but these were handled within the rubric of established common law doctrine, which everyone just assumed was consistent with constitutional requirements. ${ }^{49}$

This complacent uniformity began to deteriorate in the early years of the twentieth century under the strain of progressive and realist jurisprudence, combined with new statutory and common law actions that did not easily fit into traditional common law categories. For the first time, lawyers and judges began to ask what it really means to give full faith and credit to another state's laws. And an unexpected difficulty appeared: Taking the language of the Full Faith and Credit Clause literally would lead to "the absurd result that, wherever the conflict arises, the statute of each state must be enforced in the courts of the other, but cannot be in its own."

While this obviously was unacceptable, an appropriate altemative was not immediately apparent. One possibility was to hold that the Full Faith and Credit Clause demands the use of particular choice-of-law rules. But which rules? This approach required the Supreme Court either to freeze further development in choice of law by constitutionalizing the traditional rules, or to invest considerable time and effort in devising new ones. And either way, for the Court to have assumed this responsibility would have meant cutting off experimentation just when a failing consensus in favor of the traditional rules made it most necessary. What is more, constitutionalizing choice-of-law rules would have deprived states of a significant measure of autonomy in an area not previously thought to be exclusively federal.

The Court grappled with this problem for several years before finally settling on an acceptable solution. At first, it attempted to balance competing interests, holding that "[p]rima facie every state is entitled to enforce in its own courts its own statutes," of the parties shows "that of the conflicting interests involved those of the foreign state are superior to those of the forum." ${ }^{52}$ This left states relatively free to experiment with choice of law in most cases, but it proved difficult to administer, leading the Court to retreat further to a form of minimum contacts analysis. Under this approach, still the law today, an interested state can

49. See generally Laycock, supra note 25, at 298-301 (discussing this initual penod) Early cases to reach the Supreme Cour thus were disposed of on the presupposituon that the tradiuonal rules applied. See. e.g., Chicago \& Alton R.R. v. Wiggins Ferry Co., 119 U.S. 615, 622-24 (1887); Bonapante v Tax Cour, 104 U.S. 592, 594-95 (1881).

50. Alaska Packers Ass'n v. Industrial Accident Comm'n. 294 U.S. 532.547 (1935)

51. Id.

52. Id. at 548. 
always apply its own law without regard for the competing interests of other states. ${ }^{53}$ The Full Faith and Credit Clause serves only a modest screening function: It prohibits states with no interest from applying their laws, but does not dictate any particular choice among interested states. This leaves choice of law almost entirely in the hands of state courts, with somewhat chaotic results. Congress can always step in, however, exercising authority expressly conferred upon it in the Effects Clause. ${ }^{54}$ The Court's position is thus to minimize federal judicial interference, given the difficulty of the task involved, and to wait for Congress to act if things in the states get too out of hand.

Not everyone agrees with this approach. A number of commentators have urged the Supreme Court to impose uniform national choice-of-law rules. ${ }^{3 s}$ Others suggest that if the Court is not inclined to change its practice across the board, it might at least consider toughening the requirements of full faith and credit in selected areas; same-sex marriage, these critics suggest, is a good place to start. ${ }^{56}$

For what it is worth, I think the Court made the right decision on this question. As anyone familiar with the continuing controversy in choice of law can attest, there is still nothing remotely close to a consensus on how to think about developing choice-of-law rules. Even if we could agree on a philosophy or approach, moreover, the task of converting it into particular rules would be fantastically time-consuming and difficult, particularly if this were to be attempted case by case in constitutional litigation. The Supreme Court has reduced its docket a lot in recent years, but it still is in no position to assume this responsibility.

Nor is it feasible to think about turning the problem over to lower federal courts by overruling Klaxon $^{57}$ (as some critics have suggested) and thereby

53. See Shutts, 472 U.S. at 818-19 (1985); Hague, 449 U.S. at 312-13 (1981); Pacific Employers Ins. Co. v. Industrial Accident Comm'n, 306 U.S. 493, 502 (1939). My statement applies only to the Full Faith and Credit Clause. The Due Process Clause imposes an additional constraint in the form of protecting defendants from unfair surprise, although the Court no longer distinguishes this protection from that deriving from full faith and credit. These developments are traced, in the oblique way that cascbooks do this sort of thing, in ROGER C. CRAMTON ET AL., CONFLICT OF LAWs 258-97 (5th ed. 1993).

54. This provides: "And the Congress may by general Laws prescribe the Manner in which such Acts, Records and Proceedings shall be proved, and the Effect thereof." U.S. CONST. art. IV, $\S 1$. The Clause is discussed in greater detail infra Part III.

55. See, e.g., William F. Baxter, Choice of Law and the Federal System, 16 STAN. L. REv. 1, 32-33 (1963); Michael H. Cardozo, Choosing and Declaring State Law: Deference to State Courts Versus Federal Responsibility, 55 Nw. U. L. REv. 419, 431-36 (1960); Rober H. Jackson, Full Faith and Credit-The Lawyer's Clause of the Constitution, 45 CoLUM. L. REv. 1, 26-27 (1945); Laycock, supra note 25, at 332-34.

56. See Henson, supra note 7, at 589 (arguing that states have "strong interests" in having their marriage laws respected and that, "it is in the nation's best interest to provide all American citizens with uniformity for their expectations regarding the most basic of state-encouraged institutions"); Keane, supra note 6, at 501-08 (arguing that Full Faith and Credit Clause calls for application of only one law everywhere and that place of celebration is best choice for that law); $c f$. Habib A. Balian, Note, 'Til Death Do Us Part: Granting Full Faith and Credit to Marital Status, 68 S. CAL. L. REv. 397, 403-06 (1995) (arguing that marital decree may be converted into final judgment, giving rise to more stringent protection).

57. Klaxon Co. v. Stentor Elec. Mfg. Co., 313 U.S. 487 (1941) (holding that federal courts exercising 
freeing them to develop choice-of-law doctrine in diversity cases. ${ }^{58}$ Federal trial and appellate courts have no jurisdiction to review state courts in civil cases, and Congress is unlikely to start authorizing cross-system appeals now. ${ }^{59}$ Yet without such review, it is doubtful that state couns will follow whatever rules federal courts devise in their diversity cases; is that not, after all, the lesson of Swift v. Tyson ? $^{60}$ Besides, we have no reason to think that lower federal courts will do a better job than state cours in developing good rules or achieving uniformity. ${ }^{61}$ Finally, we should not underestimate the states' legitimate interest in preserving their autonomy in this area. There was a time when choice of law was viewed as "merely" procedural. But the modern "revolution" in the field was prompted by recognition that selecting an applicable law is part of the process of interpreting laws to define the elements of a claim or defense. ${ }^{62}$ However much one likes or dislikes the altematives generated as a result of this insight, there is no going back, and no denying the substantive nature of the problem.

As for selecting particular problems for enhanced constitutional regulation, the difficulty comes in drawing lines. The same arguments used to justify federalizing choice of law for marriage-that certain states have particularly strong interests and that uniformity is especially important ${ }^{03}$ - can be made to work for a host of other problems, making it exceedingly difficult to halt the slide down this particular slippery slope. If there is a basis for selective intervention, it presumably turns on the relative degree of disarray in the states, as this provides the most persuasive justification for federal interference. On

diversity jurisdiction must apply choice-of-law rules of stale in which (hey sit)

58. Such was the implicit suggestion of no less an authonty than Hant and Wechsler See Hexky M HART, JR. \& HERBERT WECHSLER, THE FEDERAL COURTS AND THE FEDERAL SYSTEM 63+35 (1953) The suggestion has not been embraced by their successors See RICHakd H. FalloN. JR ET AL. Hakt \& WECHSLER'S THE FEDERAL COURTS AND THE FEDERAL SYSTEM 698-99 (th ed 19\%) (challenging lirst edition's response to Klaxon).

59. Indeed, Congress recently all but eliminated the only thing even resembling lower federal court appellate review of state cours, viz. habeas corpus. See Antuterronsm and Effectuve Death Penaliy Act of 1996, Pub. L. No. 104-132, \$102, 1996 U.S.C.C.A.N (110 Stat.) 1214, 1217 (10 be codified al 28 U S C $\S 2253(\mathrm{~b}))$.

60. 41 U.S. (16 Pet.) 1 (1842) (permitting federal courts exercisung diversity junsdietion to make their own determinations of substantive common law with respect to questions of general law) Although $5 w i f t$ was consistent with doctrinal understandings in the mid-nineteenth century. the Coun also hoped that state courts would follow the federal lead, producing uniform national common law instead. as the Cuun in Ene noted, "the benefits expected to flow from the rule [in Sistft] did not accrue," because the "[p]ersistence of state cours in their own opinions on questions of common law prevenied unifurmity" Ene $R R \quad v$ Tompkins, 304 U.S. 64,74 (1938). There is absolutely no reason to think that states will be more casily led when it comes to choice of law.

61. This is especially true if, as seems likely. they follow the pluralny of states by embracing the rudderless and unhelpful "most significant relatuonship" (est of 2 RESTATENENT (SECOND) Of CONFLICT OF LAWS \$ 283 (1971). See CRANTTON ET AL.. supra nole 53, di 619

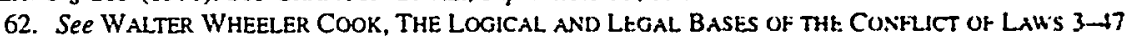
(1942); BRAINERd CURRIE, SELECTED ESSAYS ON CoNFLICT of LAll' 178 (1963). Larry Kramer. Choice of Law in Complex Litigation, 71 N.Y.U. L. REV 547, 567-79 (1996), see also infra nue 105 (discussing choice-of-law revolution).

63. See supra note 56 and accompanying texı 
that score, however, marriage ranks low on the list, as choice-of-law practice is relatively uniform and well-settled, especially in comparison to areas like tort or contract.

\section{B. The Equality Component of Full Faith and Credit}

It does not follow that just because an interested state does not have to apply another state's law, it may choose not to do so for whatever reasons or in whatever manner it wants, no more than the fact that Congress does not have to confer welfare benefits means that Congress may confer such benefits on the basis of race or religion. A greater power does not always include the lesser power to discriminate in its exercise on any basis whatsoever. It is one thing to adopt a choice-of-law rule applying forum law whenever the forum has an interest. It is quite another to adopt a rule agreeing to apply other states' laws except when these are deemed offensive. Most commentators take the constitutionality of the public policy doctrine on faith, but a good argument can be made that it violates the Full Faith and Credit Clause. ${ }^{64}$

Start with Hughes v. Fetter, ${ }^{65}$ a little known case that has received modest attention from conflicts scholars but few others. Hughes was killed in a car accident with Fetter, and the administrator of his estate (also named Hughes) brought a wrongful death action in Wisconsin against Fetter and Fetter's insurer. Although the accident occurred in Illinois, all four parties-decedent, plaintiff, defendant, and defendant's insurer-were citizens of Wisconsin. Because Wisconsin's wrongful death statute permitted recovery only for actions "'brought for a death caused within"" the state, ${ }^{66}$ the plaintiff sought relief under the law of Illinois.

The Wisconsin court held that its statute did more than just limit recovery to deaths in Wisconsin where it was the basis for seeking relief; it also established "a local public policy against Wisconsin's entertaining suits brought under the wrongful death acts of other states." ${ }^{.67}$ The state court accordingly granted the defendants' motion for summary judgment, "'dismissing the complaint on the merits." ${ }^{\prime 68}$ Note that the plaintiff's claim was not dismissed under Wisconsin's wrongful death statute. That is, the Wisconsin court did not decide to apply Wisconsin law and then dismiss because the plaintiff failed to

64. Not one of the standard treatises on conflict of laws even asks about the constitutionality of the public policy exception. A few commentators have raised the question and concluded that the exception is unconstitutional, see CuRRIE, supra note 62, at 288-89; Brown, supra note 46, at 791; Jackson, supra note 55, at 26-27; Laycock, supra note 25 , at 313 , but none of these commentators has developed the argument in any depth. I have long held this view, see CRAMTON ET AL., supra note 53, at 302-03, although the same-sex marriage controversy provides the first meaningful excuse to develop it fully.

65. 341 U.S. 609 (1951).

66. Id. at 610 n.2 (quoting WIS. STAT. $\$ 331.03$ (1949)).

67. Id. at 610 .

68. Id. (quoting Wisconsin trial court). 
allege a death occurring in Wisconsin. Rather, the court inferred that Wisconsin's wrongful death statute established an additional policy prohibiting Wisconsin courts from entertaining suits based on the wrongful death statutes of other states. Dismissal was based on this implied rule.

The Supreme Court reversed in a short, impressionistic opinion. According to Justice Black, Wisconsin could have applied its wrongful death statute to the plaintiff's claim. This would have led to the same result of dismissal, because Wisconsin required as an element of a claim that the death have occurred in Wisconsin. But the parties' Wisconsin domicile gave Wisconsin a sufficient interest to apply its law, and (as the Court had already made clear in earlier cases) ${ }^{69}$ in a conflict "between the public policies of two or more states" with legitimate interests, the forum need not defer to the interests of another state. $^{70}$

Yet this is not what Wisconsin had done. Instead, Wisconsin had adopted a policy "against permitting Wisconsin courts to entertain ... wrongful death action[s]" based on other states' laws and dismissed on that basis. Hughes thus involved a "more basic conflict" between this Wisconsin policy and "the strong unifying principle embodied in the Full Faith and Credit Clause looking toward maximum enforcement in each state of the obligations or rights created or recognized by the statutes of sister states." "In In that clash, the Court held, "Wisconsin's policy must give way."72

Hughes has long puzzled the commentators, who generally describe it as standing for some ill-defined obligation to provide a forum or explain the decision on grounds other than those offered by the Court. ${ }^{73}$ In a rather famous essay, for example, Brainerd Currie decided that the best explanation of Hughes is that Wisconsin had violated the Fourteenth Amendment's Equal Protection Clause by making the forum available to one class of its citizens while denying the same forum to another class distinguished only by the place of injury. ${ }^{74}$ Alternatively, a number of colleagues responded to an earlier draft of this Article by pointing to the fact that Wisconsin had dismissed "on the merits" and arguing that Hughes stands for the proposition that a state cannot dismiss with prejudice without applying some state's substantive law. The problem with both interpretations is that they have nothing to do with the opinion Justice Black actually wrote. The Supreme Cour made no reference

69. See, e.g., Pacific Employers Ins. Co. v. Industral Accident Comm'n, 306 U' S 493, 502 (1939). Alaska Packers Ass'n v. Industrial Accident Comm'n, 294 U.S 532. 547 (1935) (cited in Hughes, 3+1 U S at $611 \mathrm{n} .7)$.

70. See Hughes, 341 U.S. at $611-12$ \& n.10.

71. Id. at 612 .

72. Id.

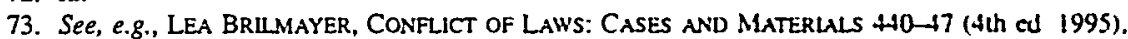
MAURICE ROSENBERG ET AL, CONFLICT OF LAWS 318-21 (10th ed 1996)

74. See Brainerd Currie, The Constirution and the "Transiton" Cause of Achon. 73 HaRV L REV 36 (1959). 
to equal protection, and while it mentioned in its description of the facts that the state court had dismissed on the merits, the point played no role whatsoever in the subsequent analysis. As Judge Friendly has reminded us in another context, "[a] court's stated and, on its view, necessary basis for deciding does not become dictum because a critic would have decided on another basis." ${ }^{.75}$ A careful reading that pays closer attention to what the Court actually said suggests that Hughes has more interesting, and broader, implications. ${ }^{76}$

The Court's opinion presents the following puzzle: What is the difference between a law that limits recovery to accidents that occur in Wisconsin-which the Supreme Court says Wisconsin could have applied-and a law that limits recovery to actions based on Wisconsin law-which the Court holds is unconstitutional? Both lead to dismissal, but only the former is allowed. Why?

One explanation might be that only the former law promotes legitimate state interests. Wisconsin may, in fact, have a number of reasons for limiting its wrongful death statute to deaths occurring in Wisconsin. The state may decide that recovery should be limited to situations that serve Wisconsin's interest in deterring negligent conduct in the state. Or Wisconsin could choose to subordinate its interests in compensation to the deterrence interests of other states by leaving their laws to govern liability for accidents occurring within their territory. Or, most plausibly perhaps, Wisconsin can justify the limitation on procedural grounds, restricting wrongful death litigation to deaths occurring in Wisconsin because witnesses and other evidence are more likely to be located within the state and so within reach of the court's subpoena power.

The result in Hughes would make sense if no similar justification were available for Wisconsin's rule limiting wrongful death actions to those based on Wisconsin law. States may not be required to defer to other states' laws if applying forum law advances a legitimate forum interest, but the forum must have such an interest. Otherwise, full faith and credit requires the court to apply the law of a state that does.

The problem with this explanation, a point hammered home by Justice Frankfurter in dissent, is that Wisconsin did have a legitimate justification for declining to entertain claims based on the wrongful death statutes of other states - the very same procedural policies used to rationalize limiting wrongful death statutes to deaths within the state:

The decision of Wisconsin to open its courts to actions for wrongful deaths within the State but close them to actions for deaths outside the

75. Henry J. Friendly, In Praise of Erie-And of the New Federal Common Law, 39 N.Y.U. L. REv. 383, 385-86 (1964).

76. The interpretation offered below also makes sense of Justice Frankfurter's dissent, which, on these alternative explanations of Hughes, is inexplicably beside the point. 
State may not satisfy everyone's notion of wise policy. See Loucks v. Standard Oil Co., 224 N.Y. 99, 120 N.E. 198 (1918). But it is neither novel nor without reason. ... Wisconsin may be willing to grant a right of action where witnesses will be available in Wisconsin and the courts are acquainted with a detailed local statute and cases construing it. It may not wish to subject residents to suit where out-of-state witnesses will be difficult to bring before the court, and where the court will be faced with the alternative of applying a complex foreign statute-perhaps inconsistent with that of Wisconsin on important issues - or fitting the statute to the Wisconsin pattern. The legislature may well feel that it is better to allow the courts of the State where the accident occurred to construe and apply its own statute, and that the exceptional case where the defendant cannot be served in the State where the accident occurred does not warrant a general statute allowing suit in the Wisconsin courts.

While not exactly overwhelming, these are unquestionably legitimate concerns. Yet if the problem in Hughes is not that Wisconsin's rule serves no appropriate ends, then what is wrong with it?

The problem is that Wisconsin had chosen an inappropriate means with which to pursue these ends. To understand Hughes, we should distinguish between two kinds of laws: those that promote a state's objectives by defining the parties' substantive rights in particular ways, and those that promote a state's objectives by withholding from state courts the power to entertain claims based on other states' laws. Most laws are of the former type, like Wisconsin's wrongful death statute limiting recovery to deaths occurring in Wisconsin. When it comes to the applicability of such laws, the Full Faith and Credit Clause has little to say. States may define substantive rights differently, and so long as the forum has a legitimate interest-so long, in other words, as we are dealing with the usual "conflict between the public policies of two or more states"78 - the forum may apply its law notwithstanding any other state's competing interest.

Laws of the second type, which can be described as discriminating against other states' laws, are different. A state that chooses to promote even legitimate objectives by directing its courts not to entertain claims based on other states' laws generates "a more basic conflict"-not just between its policy and that of another state, but between its policy and what Justice Black says is "the strong unifying principle embodied in the Full Faith and Credit Clause looking toward maximum enforcement in each state of the obligations or rights created or recognized by the statutes of sister states." this means of advancing state objectives is so directly at odds with the primary

77. 341 U.S. at 618-19 (Frankfurter, J., dissenting).

78. Id. at $611-12$.

79. Id. at 612 
objective of the Full Faith and Credit Clause, a state that uses it will have its discriminatory law subjected to heightened constitutional scrutiny.

Hughes does not make clear just how strict this heightened scrutiny is supposed to be ${ }^{80}$ On the one hand, the scope of review is plainly more stringent than rational basis scrutiny; otherwise, Justice Frankfurter would be right. Indeed, the difference between the majority and the dissent is precisely that Justice Frankfurter would uphold Wisconsin's law on the ground that it is rationally related to a legitimate state objective, whereas the Court demands something more. On the other hand, the test is apparently less demanding than strict scrutiny, a conclusion suggested by Justice Black's willingness to countenance forum non conveniens as a ground for refusing to enforce the laws of other states. ${ }^{81}$ Although forum non conveniens is justified by the same sort of reasons as those used by the dissent to rationalize Wisconsin's law in Hughes, it operates in a more refined manner: taking choice-of-law considerations into account together with a variety of other relevant factors, and leading to dismissal only when adjudication of the particular case is truly inconvenient. Wisconsin's rule, in contrast, irrebuttably presumed that every case based on another state's wrongful death statute was too inconvenient to hear in Wisconsin, and solely because it was based on non-Wisconsin law. Such discrimination is impermissibly overbroad.

An accurate statement of the holding in Hughes would thus seem to be that state rules that discriminate against the laws of other states are subject to some form of intermediate constitutional scrutiny; that is, they must be justified by substantial reasons, and the discrimination must bear a substantial relationship to the state's objectives. Nor is Hughes limited to rules that discriminate on their face against the laws of other states. In Broderick $v$. Rosner ${ }^{82}$ for example, a Depression-driven New York enacted legislation to pierce the corporate veil and make bank shareholders personally liable for a share of the bank's debts. The New York Superintendent of Banks brought an action in New Jersey to recover unpaid assessments levied against 557 New

80. It is worth observing, for the sake of clarity, that while the structure of my argument mimics analysis under the Equal Protection Clause of the Fourteenth Amendment, I neither rely on that Clause for authority nor wish necessarily to embrace all its nuances and particularities. The general notion of heightened scrutiny, requiring that a law be specially justified and more closely tailored to its ends, is associated with a number of different provisions of the Constitution, including, for example, the Privileges and Immunities Clause of Article IV, see LAURENCE H. TRIBE, AMERICAN CONSTITUTIONAL LAW $\$$ 6-35, at 532-45 (2d ed. 1988), and the First Amendment, see id. § 12-2, at 791-93. I am simply arguing that, like these provisions, the Full Faith and Credit Clause specifies a class of legislation subject to more careful scrutiny: in this case, laws that close the forum to claims based on another state's law. The lines of legal authority on which my argument rests are thus distinct from equal protection law, though the general framework of analysis is similar.

81. See Hughes, 341 U.S. at 612-13 ("The Wisconsin policy, moreover, cannot be considered as an application of the forum non conveniens doctrine, whatever effect that doctrine might be given if its use resulted in denying enforcement to public acts of other states."). Note that the Court appears to be saying that it is irrelevant whether dismissal is on the merits or not.

82. 294 U.S. 629 (1935). 
Jersey shareholders of a failed New York bank. His suit was dismissed under a New Jersey statute requiring such actions to be brought in the form of an equitable accounting in which the corporation, its officers, stockholders, debtors, and creditors were all necessary parties. ${ }^{83}$ Because of limitations on joinder and on the court's power to exercise personal jurisdiction over out-ofstate parties, bringing this action was a practical and legal impossibility - which is precisely why New Jersey required it. Justice Brandeis held that the Full Faith and Credit Clause nevertheless compelled New Jersey to entertain the suit:

A State may adopt such system of courts and form of remedy as it sees fit. It may in appropriate cases apply the doctrine of forum non conveniens. But it may not, under the guise of merely affecting the remedy, deny the enforcement of claims otherwise within the protection of the full faith and credit clause, when its courts have general jurisdiction of the subject matter and the parties. ${ }^{\text {Bs }}$

Like Hughes, Broderick has troubled commentators. Brainerd Currie, for example, found it difficult to explain why New Jersey's rule was unconstitutional. New York's expressly declared policy was to protect bank creditors by extending the liability of bank shareholders. New Jersey had adopted the opposite policy-the more familiar one of protecting shareholders through limited liability. According to Currie, if New Jersey's law is unconstitutional it must be because New Jersey had not declared this policy openly, making it, in effect, a state without an interest. ${ }^{85}$ But laws seldom include explicit declarations of policy, and courts routinely articulate these in the process of statutory interpretation. A better explanation for Broderick is that New Jersey had tried to accomplish by subterfuge what Wisconsin had done openly in Hughes: to advance its policy by depriving its courts of power to entertain suits based on other states' laws. That New Jersey did this by subterfuge was irrelevant. So long as the state intended to discriminate against claims based on the laws of other states, the Full Faith and Credit Clause's prohibition applies. ${ }^{86}$

This antidiscrimination principle is, in fact, how the Court explained Hughes in its subsequent decision in Wells $v$. Simonds Abrasive Co., ${ }^{87}$ which said that the result turned on the fact that "the forum laid an uneven hand on causes of action arising within and without the forum state. Causes of action

83. See id. at $638-39$.

84. Id. at $642-43$ (citations omitted).

85. See CuRRIE, supra note 62 , at 347.

86. Cf. Washington v. Davis, 426 U.S. 229, 245 (1976) (holding that proof of discnminatory purpose is necessary to establish violation of equal protection).

87. 345 U.S. 514 (1953). 
arising in sister states were discriminated against." ${ }^{n 8}$ But if that is the test, the public policy doctrine must be unconstitutional. For surely "offensiveness" cannot be an appropriate reason under the Full Faith and Credit Clause for refusing to entertain a claim based on another state's law. It is difficult to think of a justification more at odds with the principal mission of the Clause. On this score, I agree wholeheartedly with Doug Laycock that

Texas can reject the law of Libya in this high-handed way, or even the law of Alberta, and it may occasionally need to do so. But it cannot so treat a sister state admitted to the Union on an equal footing with itself. The public-policy exception is a relic carried over from international law without reflection on the changes in interstate relations wrought by the Constitution. ${ }^{89}$

I do not mean to suggest that Hughes and Broderick compel us to conclude that the Full Faith and Credit Clause prohibits certain forms of discrimination against other states' laws, including the public policy doctrine. Standing alone at a distance of half a century or more, these cases are too small a hook on which to hang so large an argument. ${ }^{90}$ But in Hughes and Broderick we see the Court clearly groping toward a principle that makes considerable sense in its own right. The Full Faith and Credit Clause is one of a bundle of provisions incorporated into the Constitution to bind states more closely together. These include the Privileges and Immunities Clause, the Extradition Clause, the Guarantee Clause, the Commerce Clause, and the nowdefunct Fugitive Slave Clause-all added precisely so that states would not stand in relation to one another as independent nations. With respect to full faith and credit in particular, the whole point was that states should not be free to dismiss or ignore the laws of sister states; the states were to be a community, with mutual obligations to respect each other's laws and judgments. The central object of the Clause was, in fact, to eliminate a state's prideful unwillingness to recognize other states' laws or judgments on the ground that these are inferior or unacceptable. If anything should be off-limits in such a system, it is the public policy doctrine. ${ }^{91}$

88. Id. at 518-19.

89. Laycock, supra note 25 , at 313.

90. Note, too, that Hughes presents a discrimination problem different from that posed by the public policy exception. The Wisconsin rule at issue in Hughes served a legitimate purpose but was impermissibly overbroad, whereas I am arguing that the discrimination reflected in the public policy exception does not serve a legitimate state interest.

91. Additional support for the proposition that it is inappropriate for states to discriminate against the laws of sister states may be found in analogous decisions prohibiting states from discriminating agalnst federal law. See Missouri ex rel. Southem Ry. v. Mayfield, 340 U.S. 1 (1950); Testa v. Katt, 330 U.S. 386 (1947); McKnett v. St. Louis \& S.F. Ry., 292 U.S. 230 (1934); Mondou v. New York, New Haven \& Hartford R.R., 223 U.S. 1 (1912). Although the federal/state problem obviously could be analyzed differently, the Court in these cases did not say that states were obliged to open their courts to federal claims as a matter of federal supremacy. Instead, it held that states could not decline to make a forum available solely because the plaintiff's claim was based on federal law. 
I want to emphasize the narrowness of this argument. I am not saying that states should lose their existing discretion to experiment with different choiceof-law systems or to apply their own laws where they have a legitimate interest. Nor should they be required to defer to another state simply because the other state might prefer them to do so. What is forbidden is a state's refusal to apply another state's law, otherwise applicable under forum choiceof-law rules, on the ground that it promotes a policy the forum finds repugnant. The measure of repugnance in this sense is fixed by the federal Constitution, and states have no business selectively ignoring or refusing to recognize the constitutional laws of sister states because they do not like them. A case that has contacts with another state such that the forum deems it outside the forum's sphere of interest (as defined by forum choice-of-law rules) does not slip back into that sphere because of the content of the other state's law.

It might be different were there a good argument for retaining a public policy exception - were there, in other words, an argument that the public policy doctrine serves a substantial state interest. But, as Laycock suggests, while there may be room for this doctrine in international law, it makes no sense in the context of a federal union like ours. ${ }^{92}$

Conflict of laws is, in essence, a system to enable courts from different jurisdictions to help each other enforce their respective laws. ${ }^{93}$ Imagine a world in which courts could not apply any law but their own. Forum shopping would be rampant, and the law would lose all chance of being uniform and predictable. States would be unable to enforce their laws whenever parties litigated elsewhere. They could, to be sure, enforce their laws in cases litigated in their courts, but that is desirable only if the cases litigated in each state happen also to be those implicating that state's policies to the greatest extent-a coincidence unlikely to be realized in practice. ${ }^{94}$

Questions of federalism have been much in the news, and the Court. of late As has been true throughout American history, however, the controversy has mostly concerned quesuons of Congress's power to displace state substantive regulation. Interstate relations. including the extent to which these are regulated by the Constitution, have seldom caused similar difficulties. No one quesuons that provisions like the Full Faith and Credit Clause and the Privileges and Immunities Clause are designed to limit the sovereignty of states vis-a-vis one another, and over time, the Supreme Coun and Congress have steadily extended the scope of these duties with little opposition. Since the 1960s, for example, the Coun has significantly narrowed the traditional exception to full fwth and credit for judgments rendered by a court lacking subject matter jurisdiction. See Matsushita Eloc. Indus. Co. v. Epsern, $116 \mathrm{~S} \mathrm{Ct.} 873$ (1996); Durfee v. Duke, 375 U.S. 106 (1963). Similarly, Congress has enlarged the extent to which child custody decrees are entitled to recognition in sister states. See 28 U.S.C. $\$ 1738 \mathrm{~A}$ (1994).

92. See Laycock, supra note 25, at 259-61,312-13; see also infra lexi accompanying notes 98-101

93. This paragraph and the next summarize arguments I have developed at grealer length elsewhere See Larry Kramer, On the Need for a Uniform Choice of Law Code. $89 \mathrm{M}$ (ICH. L. REV 2134 (1991): Larry Kramer, Rethinking Choice of Law, 90 CoLUM. L. REv. 277. 311-44 (1990) lhereunafter Kramer. Rethinking]; Larry Kramer, Resum of the Rernoi, 66 N Y U L REV. 979. 1015-28 (1991) (hereinafter Kramer, Renvoi].

94. Here is another way to see this last pount: Suppose we array the unverse of potentual cases along a continuum running from those a state decms most important to those of litte or no interest to it. How 
These problems can be reduced (although never entirely eliminated) by a system that recognizes the transitory nature of legal claims and allows parties to litigate in different jurisdictions without necessarily changing the applicable law. Choice-of-law rules thus serve two purposes: (1) they identify the most appropriate law to govern particular cases, ${ }^{95}$ and (2) they provide a mechanism for cooperative decisionmaking by courts in different jurisdictions. The success of the rules, whatever they are, depends on the willingness of courts in different states to recognize and enforce each other's laws. ${ }^{96}$ If the task becomes too onerous or otherwise undesirable, cooperation may break down. Hence, a choice-of-law system must temper the desire to encourage recognition of other states' laws with a realistic assessment of the burdens that cooperation imposes. These burdens include the discomfort or unwillingness a court may feel if asked to enforce laws contrary to its or its state's understanding of justice and fairness.

Consider two alternatives for addressing this concern: We could insist upon rigid enforcement of the choice-of-law rules, without regard for how the forum views the justice of the applicable law, or we might urge courts to follow the rules most of the time while leaving them an out when faced with laws they deem particularly undesirable. In the abstract, it is not obvious which approach is better. The first alternative maximizes compliance only if states continue to cooperate. The risk is that some courts, if too often required to apply laws they deem unjust, may opt out of the system altogether. Defection by a few states could easily trigger a more widespread breakdown in the system. The second alternative avoids this hazard by making a public policy exception available as a sort of safety valve: Courts can preserve their sense of justice by opting out on a selective basis. This alternative poses a different danger, namely, that courts will engage in widespread cheating, exploiting the exception to refuse recognition to foreign laws in too many cases. This, too, may lead to a breakdown. More likely, it will lead to what game theorists call a suboptimal equilibrium, in which the system survives but with pervasive underenforcement.

Obviously, the choice between these alternatives depends on empirical predictions about how courts will behave under each of them. ${ }^{97}$ In the

likely is it that the cases parties choose to litigate in the forum will all be at the high-interest end of this range?

95. What makes a law "most appropriate" is, of course, a matter of considerable controversy. For present purposes, however, that controversy is beside the point because the argument is equally applicable to any choice-of-law system. The implications of my argument for different approaches to choice of law are discussed infra Section II.C.

96. This does not mean that every state must use the same rules or apply those rules identlcally, although the greater the uniformity, the more successfully the system as a whole will operate. See Kramer, Renvoi, supra note 93 , at 1021-28.

97. My analysis insists that the public policy doctrine cannot be justified on the ground that it enables courts to choose the better or more just law. The whole problem in a conflict case is that different states have made different judgments about what is best, and it is axiomatic that, except as constrained by the 
international context, something like a public policy exception emerged early and has remained an integral part of the law. As noted above, ${ }^{98}$ the exception was incorporated into American practice with no particular thought given to its propriety in the context of our federal system. It is apparent, however, that while several features of international litigation may make it sensible to minimize stress by leaving an escape device in the form of the public policy exception, the states of the United States are situated differently from the nations of the world in this respect.

First, the nations of the world have widely disparate cultures and values, as well as radically inconsistent legal systems. This means that both the number of cases in which courts are asked to enforce laws they deem unjust and the extent to which these laws are deemed offensive are likely to be great. Insisting that courts rigidly enforce choice-of-law rules without regard for the substantive content of the laws they are asked to enforce could thus generate a great deal of stress in the system. The states of the United States, in contrast, share what is, for practical purposes, a single culture. There are, to be sure, regional differences, but these are more the stuff of late-night TV jokes and friendly sports rivalries than of armed struggle. Our basic values are widely shared and, equally important, our legal systems overlap to an extraordinary degree. Disagreements arise, of course, often with the same intensity as in international cases, but they arise less frequently and on many fewer issues than in international relations. This is attributable in part to the federal Constitution, which takes a number of contentious problems off the table for individual states and screens out laws inconsistent with widely shared national values.

Second, the primary glue that holds the international system together is the self-interest of the nations involved. Particular calculations of self-interest are not the only ties that bind, but one cannot rely too much on a sense of shared mission or moral obligation in international relations. Nations will not hesitate to abandon a cooperative venture if doubts arise about whether it is genuinely worth their while to adhere to it. The states of the United States, in contrast, share a strong sense of mission and mutual obligation, at least in comparison to the international setting. Indeed, few citizens today think of the United States as anything other than a single political community. While states still compete with one another, their relations are characterized by a large degree

Constitution, states are coequal sovereigns entilled to make their own value judgments (something I had thought was settled by Erie R.R. v. Tompkins, 304 U.S. 64 (1938)). Euch state is free to define ths own version of the "just" result, and no general law limits or controls any state's power in this regard. Conflicts thus present competing but equally legitimate versions of what is just. The problem is how best to take into account the fact that states often disagree, without trashing the whole system The public policy doctnne is one way to accommodate occasional strong disagreements about policy. The question whether it is a good one thus cannot be resolved by reson to a general theory of justice. an least not in a mulujunsdictional system in which not all jurisdictions share the same theory or interpret their theones identically

98. See supra note 25 and accompanying text. 
of what international theorists call "diffuse reciprocity," a generalized commitment in which self-interested calculations of expected utility are replaced by a general willingness to let things play out in the long run. ${ }^{99}$

Third, no formal enforcement mechanism exists in international law to prevent nations from defecting. Indeed, nothing prevents defection except the threat of reciprocal defection. This fact is particularly significant in light of the first two, which suggest that defections may come easily in the international context. In the United States, by contrast, an enforcement mechanism other than the threat of mutual defection is available in the Supreme Court and the federal government. It may be too much to ask the Court to devise a comprehensive system of choice-of-law rules. It is not unrealistic, however, to expect the Court to enforce a simpler pledge to remain within a cooperative system by prohibiting outright defection and by requiring states to lend each other a helping hand. Indeed, as the full faith and credit cases demonstrate, the Court has already recognized its responsibility in this respect.

Given these differences, a public policy exception that may be justifiable in international cases makes little or no sense in the United States. It is unnecessary and counterproductive, as well as inconsistent with the premises of the Full Faith and Credit Clause. To prevent states from discriminating in their treatment of other states' laws based on content may produce some small amount of stress, but not nearly enough to justify tolerating the widespread cheating that the public policy doctrine invites.

This analysis suggests that there is a difference between domestic and international cases, one that would allow (though not require) state courts to treat the laws of other nations differently than they treat the laws of sister states. The distinction is, I believe, fully justified by the dissimilar settings I have outlined. Nor is there anything unusual about treating international cases differently. Such differences are familiar in choice of law, as illustrated, for example, by rules allowing courts to take judicial notice of the laws of other states while requiring proof of the laws of foreign nations. ${ }^{100}$ As a constitutional matter, moreover, we should recall that the "very purpose" of the Full Faith and Credit Clause was "to alter the status of the several states as independent foreign sovereignties, each free to ignore obligations created under the laws or by the judicial proceedings of the others, and to make them integral parts of a single nation." 101 The relationship among the states is supposed to be different.

99. See Robert O. KeOHANe, INTERNATIONAL InStITUTIONS AND STATE POWER 134-49 (1989); Robert O. Keohane, The Demand for International Regimes, in INTERNATIONAL REGIMES 141 (Stephen D. Krasner ed., 1983).

100. See Gregory S. Alexander, The Application and Avoidance of Foreign Law in the Law of Conflicts, 70 Nw. U. L. REV. 602, 605 (1975).

101. Milwaukee County v. M.E. White Co., 296 U.S. 268, 276-77 (1935). 
Perhaps the most serious objection to my argument that the public policy doctrine violates the Full Faith and Credit Clause is Justice Scalia's protest that a practice, constitutional at the Founding and in constant use since then, cannot suddenly become unconstitutional. ${ }^{102}$ The argument is a variation of the standard refrain about a countermajoritarian difficulty, stronger in the sense that Scalia offers continuous usage as a sort of popular reaffirmation that makes judicial interference even tougher to justify. Yet the apparent applicability of this argument to the public policy doctrine is deceptive. There was, to be sure, a principle bearing some resemblance to the public policy doctrine already in existence in 1789. It was, however, a distant forebear at best-not yet named, limited to dismissal for want of jurisdiction, and narrowly confined in scope. The widespread use of a formal "public policy exception" as a ground for applying forum law is, in fact, of much more recent vintage. ${ }^{103}$

Even where it applies, moreover, the argument from tradition is easily overstated. A long pedigree naturally will cause any conscientious judge to hesitate before declaring a practice unconstitutional-and so it should. Yet pedigree alone cannot pose an insurmountable barrier in the face of a strong challenge based on precedent and principle. Judges are supposed to interpret and apply the law in a way that maintains consistency with its spirit and purpose as well as its letter and form. We call them judges because we expect them to exercise judgment. Otherwise, we could just turn the justice system over to a well-programmed computer. Exercising judgment carries with it an obligation to interpret laws in conformity with changing circumstances; standing still while everything else changes is either ignorance or omeriness, not fidelity to law. And this interpretive obligation extends to changing values and understandings as well as material circumstances. ${ }^{105}$ Whatever role the

102. See Pacific Mut. Life Ins. Co. v. Haslip. 499 U.S 1, 35-36 (1991) (Scalı, J , concurnng in judgment) (discussing jury discrecion in awarding punuve damages), see also Bumham $v$ Supenor Court. 495 U.S. 604 (1990) (discussing transient jurisdictuon); Sun Oil Co. s: Wonman, 486 C' S 717 (1988) (applying forum statute of limitations).

103. Joseph Story's Commentaries, for example, makes no reference to a public policy docinne Cases that tum on considerations similar to those encompassed by the public policy doctnne are. instead. presented as particular exceptions to general rules. There are relauvely few such exceptuons in the treatuse. and Justice Story urges readers to keep it that way. See STOKY, supra notc 10, at 205-26 (discussing exceptions to place of celebration rulc for mamages): $1 d$. at 371-72 (discussing exceptuons to rule that contract is valid if valid in place where made). A general "public policy" exception that cuts across nules seems not to have achieved recognition until sometume in the late nineleenth or early iwenticth century. after which time discussions of the doctrine become mure common. Sec. e g. ERNisT G LOREN]EV. SELECTED ARTICLES ON THE CONFLCT OF LAwS 12-17 (19.47) (citung authonties) As late as 1934. however, the Restatement was still describing the public policy exception as "extremely limited." whule emphasizing that courts invoking it dismiss without rendenng a decision on the merts Sec ResTateutevt OF THE LAW OF CONFLICT OF LAWS $\$ 612 \mathrm{cmts}$. a, c (1934).

104. Examples here could be multiphied almost without end Thank of Roc s Whak. 410 US 113 (1973), Miranda v. Arizona, 384 U.S. 436 (1966). Gideon , Wamuright. 372 US 335 (1963). and Brown v. Board of Education, 347 U.S. 483, (1954), to name but a few of the most well-knoun cases For present purposes, Erie R.R. v. Tompkins, 304 U.S. 64 (1938), provides a particulialy apt illustration $A$ comerstune of the modem federal system. Erie held that Sw ff v Tison. \&1 L S (16 Pet ) I (Is+2), was unconstitutional 
public policy doctrine may once have played, or however much sense it may once have made, no longer matters. The doctrine has evolved into something different from what it was at the start, expanding even as it became more incompatible with our growing sense of what states owe each other. It no longer makes sense.

\section{Implications for Choice-of-Law Analysis}

To say that the public policy exception is unconstitutional is already to propose a fairly substantial change in the law. But the premise for the exception's unconstitutionality has broader implications that need to be examined as well. Recall the argument: Full faith and credit prohibits states from basing choice-of-law decisions on the desirability or obnoxiousness of other states' policies. Thus stated, the principle appears to threaten a great deal of modern choice-of-law doctrine in addition to the public policy exception. In fact, the consequences of accepting the argument are considerably less catastrophic.

Conflicts scholars like to describe the choice-of-law revolution ${ }^{105}$ as a victory for "policy analysis," which is why a principle that appears to prohibit policy-based choices seems so ominous. If modern choice-of-law analysis asks courts to make policy-based choices, however, it does so in a special and

insofar as it authorized federal courts to make their own determinations of common law in diversity cases. Yet Swift was consistent with the understanding of the common law that prevailed when the Constitution was adopted and was unquestionably constitutional when it was decided (which is why we did not hear states' righters howling about federal usurpation at the time). See CRAMTON ET AL., supra note 53, at 591-92; Lawrence Lessig, Fidelity and Constraint, 65 FordHAM L. REV. 1365, 1401-08 (1997). Moreover, the practice Swift endorsed was continuous and, if anything, still spreading in 1938. Was the Court wrong to overrule Swift? Of course not. However much sense Swift may once have made, changes in our understanding of the common law and the federal system made it an unhealthy anomaly that necded to be put to rest. So too the public policy doctrine.

105. Readers unfamiliar with these developments in choice of law will find a useful summary in LBA BRILMAYER, CONFLICT OF LAWS: FOUNDATIONS AND FUTURE DIRECTIONS chs. $1-2$ (2d ed. 1995). The basic story is well-known, however, for it is the familiar tale of the abandonment of formalism for realism. Traditional choice-of-law doctrine offered a paradigmatic example of what we have come to call (after Roscoe Pound) "mechanical jurisprudence." It consisted of broad rules derived from an abstract theory (here, of territoriality) and applied without consideration for functional objectives or consequences. This doctrine was subjected to devastating criticism from progressive and realist scholars in the early years of the twentieth century, the gist of which underscored the need to analyze choice-of-law problems in terms of consequences for the policies at stake. But whereas the implications of this critique were absorbed gradually in most fields from the turn of the century through the 1950 s, choice of law remained curiously static. It was not until the early 1960s that cours began finally to abandon the traditional choice-of-law rules; first honors here are typicaliy awarded to the New York Court of Appeals for its opinion in Babcock v. Jackson, 191 N.E.2d 279 (N.Y. 1963). See Symposium on Conflict of Laws: Celebrating the 30th Anniversary of Babcock v. Jackson, 56 ALB. L. REv. 693 (1993). After Babcock, change came rapidly. Scholars had already proposed a variety of new approaches to choice of law, and each of these soon found adherents in the courts of a few states. In less than a decade, the choice-of-law landscape was completely transformed. A common feature of all these new approaches was the abandonment of formal rules for some kind of functional analysis that takes choice-of-law policies into account together with the polictes underlying the substantive laws in conflict. Hence scholars refer to a choice-of-law "revolution" marked by the acceptance of some form of policy analysis. 
limited sense of the term. The problem with traditional choice-of-law rules was that they were policy blind. Each rule selected a contact to determine the applicable law for a particular type of controversy, but the contact was not chosen for its relationship to any substantive policies underlying the law in such controversies, and whatever tendency it had to advance these policies was coincidental.

Take, for example, the traditional place of injury rule in tort cases, which provides that the law where the plaintiff was injured shall determine the parties' rights and liabilities with respect to all of the substantive issues in a case. The choice of the place of injury had nothing to do with tort policy but was based on classic formalist logic: The cause of action necessarily arose at the place where the tort was completed, and "[t]he tort is complete only when the harm takes place, for this is the last event necessary to make the actor liable." ${ }^{106}$ Now suppose that a married couple from Texas has an accident in California, and the question is whether one spouse can sue the other. Both states presumably have rules governing this situation; suppose, for instance, that Texas permits such suits while California bars them. Each state's rule reflects the judgment of that state's lawmakers about how best to regulate intrafamilial relations and the likelihood of fraud or collusion-policies that are implicated if the couple resides in the state, without regard for where they were injured. The application of California law to bar the suit under the place of injury rule thus frustrates Texas policy while serving no legitimate Califomia interest, and is utterly senseless.

The familiar critique of traditional choice-of-law rules for failing to take policy considerations of this sort into account was developed decades ago, with great thoroughness, by realist and legal process scholars. ${ }^{107}$ As one might have expected, their advice was to do the opposite: to base choice-of-law decisions on the way in which a state's contacts with a case implicate choiceof-law policies and the policies underlying each state's potentially applicable laws. Brainerd Currie led the way, developing the first workable alternative to

106. HERBERT F. GOODRICH, HANDBOOK OF THE CONFLICT OF LAWS $\$ 93$ (3d ed. 19.9) The court in Alabama G.S.R. Co. v. Carroll, 11 So. 803 (1892), explained:

The fact which created the right to sue, - the injury.-without which confessedly no action would lie anywhere, transpired in the state of Mississippi. It was in that state. therefore. necessarily that the cause of action, if any, arose: and whether a cause of action arose and existed at all, or not, must in all reason be determined by [that law].

Id. at 806; see also RESTATEMENT OF THE LAW OF CONFLICT OF LAw' $\$ 377$ (1934) As I have clsewhere pointed out, even the formal reasoning behind this rule is fallacious. See Larry Kramer, Vesfiges of Beale Extraterritorial Application of American Law, 1991 SUP. CT. REV. 179. $190 \mathrm{n.36}$ ("The last event test is arbitrary because there is no claim unless all the elements are established. A tort may be consummated where the last act occurs, but it is being commined from the first to the last act and thus 'occurs' at all these places.").

107. See supra note 105. The classic treatments include COOK, supra note 62; LOREvEEx, supra notc 103; David F. Cavers, A Critique of the Choice-of-Law Problem, 47 HARV. L. REV. 173 (1933); and, of course, Brainerd Currie, Married Women's Contracts: A Siudy in Confici-of-Lows Method, 25 U CHI. L. REV. 227 (1958). 
the traditional rules with his "governmental interest analysis."108 Currie was followed by others who built on the same insights but developed quite different approaches: the "most significant relationship" test of the Second Restatement, ${ }^{109}$ Baxter's "comparative impairment" analysis, ${ }^{110}$ Leflar's "choice-influencing considerations,"

108. See CURRIE, supra note 62 , at chs. $1-4$. Under this approach, a court is supposed to ascertain the purposes served by each state's law and ask which state has contacts that implicate the purposes of that law; a state that has such contacts is said to have a "governmental interest" in the case (commentators today just say "interest") and thus a legitimate claim to have its law applied. If only one state is interested, the case presents a "false conflict," and the law of the only interested state applies. If more than one state is interested, the case presents a more difficult "true conflict." After much agonizing, Currie concluded that true conflicts should normally be decided by applying the law of the forum, as should cases in which no state is interested (called "unprovided for" cases) and in which a true conflict is litigated in a disinterested forum.

Currie has been criticized for emphasizing the policies underlying substantive laws to the exclusion of more general choice-of-law policies, like minimizing forum shopping and enhancing uniformity and predictability. See Alfred Hill, Governmental Interest and the Conflict of Laws-A Reply to Professor Currie, 27 U. CHI. L. REv. 463 (1960); Arthur Taylor von Mehren, Recent Trends in Choice-of-Law Methodology, 60 CORNELL L. REV. 927, 938 (1975). Currie does, in fact, take such multistate policies into account when it comes to resolving true conflicts, though concededly he did not place much stock in them or give them much weight. See CURRIE, supra note 62, at 52-53; Brainerd Currie, The Disinterested Third State, 28 LAW \& CONTEMP. PROBS. 754, 757 (1963) (arguing that many true conflicts can be resolved by taking "moderate and restrained" second look).

109. 1 RESTATEMENT (SECOND) OF CONFLICT OF LAWS (1971). Section 6 of the Second Restatement says to decide each issue in a case according to the law of the place with the "most significant relationship" to that issue, as determined by a long list of factors. The factors include:

(a) the needs of the interstate and international systems, (b) the relevant policics of the forum,

(c) the relevant policies of other interested states and the relative interests of those states in the

determination of the particular issue, (d) the protection of justified expectations, (e) the basic policies underlying the particular field of law, (f) cerainty, predictability and uniformity of result, and $(\mathrm{g})$ ease in the determination and application of the law to be applied.

Id. \$ 6. The Second Restatement includes a multitude of rules designed to identify the state likely to have this "most significant relationship" in any given situation, but these are mere presumptions and may be ignored if the cour determines that some other state has a more significant relationship under section 6 . By far the most widely used alternative to the traditional rules, see CRAMTON ET AL., supra note 53, at 132, the Second Restatement has been harshly criticized by academic commentators. See, e.g., Larry Kramer, Choice of Law in the American Courts in 1990: Trends and Developments, 39 AM. J. CoMP. L. 465, 486-87 (1991) ("'Olne needs to read a lot of opinions in a single sitting fully to appreciate just how badly the Second Restatement works in practice."); Laycock, supra note 25, at 253 ("Trying to be all things to all people, it produced mush."); Joseph William Singer, Real Conflicts, 69 B.U. L. REV. 1, 77 (1989) ("The Second Restatement's silence regarding the priority of [section 6] policies mystifies rather than clarifies .....").

110. See Baxter, supra note 55. In this insightful article, Baxter asks what would happen if lawmakers from two states were to negotiate a multistate agreement on the respective application of their laws in conflict cases. He then reasons that courts can replicate the likely outcome of such multistate negotiations with a principle of "comparative impairment": "to subordinate, in the particular case, the external objective of the state whose internal objective will be least impaired in general scope and impact by subordination in cases like the one at hand." Id. at 18. A state's "internal objective" is the policy that led the state to enact a law for domestic cases; a state's "extemal objective" is its desire to extend that law to multistate cases that implicate the state's internal objective. See id. at 17. In other words, Baxter concludes that courts should resolve conflicts by applying the law of the state whose domestic policy would be more impaired if that state's law were not applied. This approach, Baxter argues, maximizes the likelihood that each state's law will be applied in the cases that are most important to it. See id. at 8-10. Baxter's analysis has becn adopted by the courts in California. See Bernhard v. Harrah's Club, 546 P.2d 719, 720-21 (Cal. 1976); Herma Hill Kay, The Use of Comparative Impainment to Resolve True Conflicts: An Evaluation of the California Experience, 68 CAL. L. REV. 577, 577 (1980).

111. Robert A. Leflar, Choice-Influencing Considerations in Conficts Law, 41 N.Y.U. L. REV. 267 (1966). After examining cases to ascertain the "true" reasons for decision, Leflar produced a list of five 
preference,"112 and so on.

Significantly, with the sole exception of Leflar, these new theories were all carefully constructed to make sure that choice-of-law decisions would not turn on judgments about the desirability or obnoxiousness of the conflicting substantive policies. They were, or tried to be-dare I say it?-policy neutral. Thus, unlike the blind choices made by traditional rules, choices under these new theories are indeed policy based inasmuch as they tum on whether a state's contacts affect relevant substantive and choice-of-law policies. But this does not include asking whose substantive policy is preferable or superior from some external perspective. On the contrary, pains were taken to ensure that this not be a basis for resolving conflicts.

Currie, for example, argued that a law should apply only if the state's contacts relate to the law's underlying domestic policies: If a law serves compensatory interests, the question is whether one of the parties is from the state; if the law seeks to encourage or discourage particular conduct, the question is whether the conduct at issue took place within the state, and so forth. In this sense, certainly, interest analysis is policy based. But Currie went to great lengths to emphasize that it was inappropriate to resolve cases in which more than one state has such contacts (so-called true conflicts) by assessing the relative merit of their respective substantive policies. Hence, he

"choice-influencing considerations" that he claimed encompassed the factors used to determine choice-oflaw results. These are: (1) predictability of result; (2) mantenance of the interstate and intemational order: (3) simplification of the judicial task; (4) advancement of the forum's governmental interests (including its interest in doing justice by sometimes applying another state's law): and (5) applicalion of the better rule of law. See id. at 282. Because of this last factor, by far the most controverstal. Leflar's method is often called the "better law" approach. It has been adopted by cours in six states: Arkansas. Hawall. Minnesota, New Hampshire, Rhode Island, and Wisconsin. See CRAMTON ET AL., supra note 53, al 217 In practice, courts that follow Lefiar's approach resolve most cases without relying on or emphasiang the better law factor. When this factor does come into play, judges ask such questions as whether a law is anachronusuc (measured by what other states are doing), and whether it is over- or undernelusive in the way $t$ achieves its stated ends. Unavoidably, at least some cases that turn on better law analysis require the coun to make a straightforward value judgment about the desirability of the respective substantive policies. See. $\&$. Milkovich v. Saari, 203 N.W.2d 408, 417 (Minn. 1973) ("In our search for the better rule, we are firmly convinced of the superiority of the common law rule of liability to that of the Ontano guest statule ")

112. See David F. Cavers, The ChoICE-OF-LAw Process (1965). Cavers aruculated a senes of seven "principles of preference" to use in resolving conflicts. With respeat to ton actions. for example. Cavers's first principle provides that the law of the place of injury should apply if it is more protective of the plaintiff than the law of the states in which the defendant resides or acted. See id. at 139-45 His second principle, a corollary of the first, provides that the law of the state where a defendant acted and caused injury should apply if it is less protective than the law of the plaintiff's home stale. See ut at 146-59 Both principles are justified on the basis of the parties' reasonable expectations. Other ton pnnciples deal with cases in which one state imposes "special controls" over particular conduct within its borders, such as blasting or the sale of liquor (apply that state's law), see id. at 159-66, and cases in which parties have established a relationship of some sor, such as the purchase of a tucker (apply the law of the "seat" of this relationship if it is more protective of plaintiffs than the law of the place of injury). see id al 166-76. Cavers takes care to indicate that these principles do not consutute a complete choice-of-law system and that he is merely offering a guide with which to develop addiuonal rules. For a case in which Cavers's principles of preference played a central role, see Cipolla v. Shaposka, 267 A.2d 854. 856-57 (Pa. 1970). which relies on Cavers's second principle to preclude recovery under a Delaware guest statute in an action brought by a Pennsylvania guest against his Delaware host for an injury incurred in Delaware 
eventually concluded, the only safe solution is to apply forum law. ${ }^{113}$

The few judges and theorists who follow Currie's approach have consistently adhered to this advice. ${ }^{114}$ A much larger number embraced Currie's basic insights but were not persuaded to adopt his alternative solution to true conflicts. So they looked for other answers, but answers that, like Currie's, did not turn on substantive policy preferences. Baxter's "comparative impairment" analysis and Cavers's "principles of preference," for example, are both best understood as efforts to resolve true conflicts without an automatic forum preference but still on grounds other than declaring one state's substantive policy to be better or more desirable. ${ }^{115}$ This is true also of my own efforts to resolve conflicts by developing tie-breaking canons. ${ }^{116}$ Even courts and commentators who struck out in different directions-lex fori, significant contacts, center of gravity, and the like ${ }^{117}$-were always careful

113. See CURRIE, supra note 62 , at 117-21, 181-82.

114. See, e.g., Lilienthal v. Kaufman, 395 P.2d 543, 546 (Or. 1964); Herma Hill Kay, A Defense of Currie's Governmental Interest Analysis, 215 RECuEIL DEs CouRs 9, 151-52 (1989); Robert A. Sedler, Interest Analysis and Forum Preference in the Conflict of Laws: A Response to the 'New Critics', 34 MERCER L. REV. 593 (1983). In later work, Currie modified his approach to recognize the appropriateness of reexamining forum law "with a view to a more moderate and restrained interpretation both of the policy and of the circumstances in which it must be applied to effectuate the forum's legitimate purpose." Curric, supra note 108 , at 757 . Even here, Currie was careful to avoid judgments about the relative merits of the conflicting policies. Hence, he offers Bernkrant v. Fowler, 360 P.2d 906 (Cal. 1961), as a "brilliant[]" example of the sort of inquiry he had in mind. See Currie, supra note 108, at 757. In Bernkrant, Justice Traynor resolved an apparent true conflict between California and Nevada law by concluding that California would not apply its law because the particular facts made it reasonable for the partics to assume that Nevada law applied (the parties were all Nevada residents at the time of the transaction). See 360 P.2d at 909.

115. See supra notes 110,112 .

116. See Kramer, Rethinking, supra note 93, at 315-38; Kramer, Renvoi, supra note 93, at 1015-21. This work reinterprets and modifies Baxter's comparative impairment analysis, discussed supra note 110. Because Baxter asked judges to make a determination that is too complex and difficult to be practical, I proposed instead to develop a set of "policy-selecting" rules or canons that would direct courts to choose the law that reflects a generally shared policy or policy preference. In this way, all states may systematically advance their more important interests. These rules are not based on value judgments about which rules are normatively superior. Indeed, they are specifically designed to avoid such inquiries. Take the canon that where one of two conflicting laws is obsolete, the other law should be applied. See Kramer, Rethinking, supra note 93, at 334. This could be read to assume that nonobsolete laws are substantively preferable to obsolete ones, and so some readers appear to have misunderstood it; I defined obsolete to mean "inconsistent with prevailing legal and social norms in the state that enacted it" (as opposed 10 inconsistent with norms prevailing in other states) precisely to avoid such judgments. Id. The assumption is that laws that are obsolete in this restricted sense probably remain on the books as a matter of inertia; to the extent such laws reflect any policy at all, it is a weak, vestigial commitment. Moreover, every state has some laws that are obsolete in this sense, and these laws are bound to come into conflict from time to time with the nonobsolete laws of other states. If I am right that obsolete laws represent weakly-held policies, then every state is better off if it resolves such conflicts by applying the nonobsolete law, since in the long run such a rule will systematically advance the more strongly-held policies of all states. See id. at 335-36.

117. These approaches are variations of the more well-known approaches discussed above. See supra notes 108-12. Lex fori calls for application of forum law whenever the forum has contacts sufficient to make this constitutional. See BRILMAYER, supra note 73, at 361-66; cf. ALBERT EHRENZWEIO, CONFLICT OF LAWs 349-51 (1962) (recognizing exceptions only for universally shared "true rules" revealed by results in decided cases). The "significant contacts" and "center of gravity" approaches, in contrast, are variations on the Second Restatement; like the Restatement, both direct the judge to ask which state has the "most significant" contacts, but in a way that is less systematized and more fact-bound. See CRAMTON ET AL., 
to avoid comparative evaluations of the intrinsic worthiness of the policies at issue.

Not every modern approach shares this commitment to resolving conflicts without evaluating the merit of different states' substantive policies. In particular, evaluations of this sort are made by courts and commentators employing some version of "better law" analysis. ${ }^{118}$ If my interpretation of the Full Faith and Credit Clause is right, this inquiry is (or ought to be deemed) unconstitutional. But before conflict-of-laws mavens begin sputtering, note how insignificant the practical consequences of this would be, even in the six states that use a better law approach. ${ }^{119}$ For in none of these states is the "better law" inquiry made in every case. It is, rather, a final step, reached only after the judge concludes that a case cannot be resolved on the basis of other "choice-influencing" considerations, none of which is affected by my argument. Because these other considerations dispose of the vast majority of cases in practice, eliminating "better law" analysis will have only marginal effects on choice of law.

Two observations put the relevant lessons here into perspective. First, because most choice-of-law analysis does not ask about the desirability or obnoxiousness of other states' policies, my argument that full faith and credit prohibits states from making choice-of-law decisions on this basis leaves existing doctrine relatively undisturbed. The public policy exception should no longer be used, of course, and better law analysis similarly ought to be found unconstitutional. Yet while these are not insignificant changes, choice-of-law methodology can for the most part continue to develop just as it has for the past century. Second, the very fact that courts and commentators have tried so hard to avoid making choice-of-law decisions turn on evaluative judgments about substantive policy provides strong support for my argument. Most commentators, to be sure, have not seen the problem in constitutional terms. But the argument for making it constitutional-suggested by cases like Hughes and Broderick and motivated by the core values of full faith and credit-is straightforward. That virtually everyone who works in the field recognizes the inappropriateness of making choices turn on such evaluations is a lesson worth keeping in mind.

supra note 53, at 117-18; Symeon C. Symeonides. Choice of Law in the American Courts in 1995: A Year in Review, 44 AM. J. CoMP. L. 181, 193-94 (1996). Couns that employ these approaches someumes talk about "balancing" interests, but this means evaluating which state has eloser or stronger connecuons, not whose law is better. Such balancing can be faulted for being unprincipled. nonanalyuc. even incoherent. But it does not turn on substantive policy preferences and so does not suffer from the infirmity condemned in this Article.

118. See supra note 111. Other commentators who have adopted forms of better law analysis unclude Singer, supra note 109; and Friedrich K. Juenger, A Critique of Interest Analysis. 32 AM. I COMP. L. 1 (1984).

119. See supra note 111. 


\section{Implications for Marriage Cases}

What consequences does the argument portend for marriage cases in particular? We saw in Part I that courts tend to follow the place of celebration rule pretty much without regard for how they resolve other choice-of-law problems, and that the public policy exception is the ground most often used to deny recognition to marriages performed elsewhere. It follows that, under existing law, public policy will almost certainly be the basis for invalidating same-sex marriages performed legally in Hawaii.

One effect of my argument, then, is to constrain the ability of states to invalidate same-sex marriages without somehow changing their choice-of-law rules for marriage generally. This is true whether states express the desire to deny recognition by statute or by judicial decision, since the Full Faith and Credit Clause is equally binding on state legislatures. More important, it is true whether states adopt an express exception for same-sex marriages or instead invent ways to accomplish the same end without openly saying so, for the constitutional prohibition similarly reaches facially valid rules adopted for an improper purpose. ${ }^{120}$

Thus, a state could not apply an ostensibly non-content-based marriage evasion statute only to same-sex marriages. Nor could a state's lawmakers simply replace their broad rule governing "marriage" with more discrete rules for particular marriages in a way designed to single out the law of particular states for discriminatory treatment-adopting, for example, a place of celebration rule for opposite-sex marriages and a place of domicile rule for same-sex marriages. Insofar as such rules are designed to recognize other states' laws except where these validate same-sex marriages, attempting to do by subterfuge what the state is forbidden to do openly, they too would be unconstitutional. ${ }^{121}$

How should we expect states to respond to this new regime? Some states might give up their plans to single out same-sex marriages celebrated lawfully in Hawaii, sticking with the place of celebration rule even without a public policy escape device. Others probably will adopt one of the modern approaches

120. See supra notes $82-86$ and accompanying text.

121. Apart from this, states remain free to rewrite their choice-of-law rules as they please. A state could adopt, for example, a place of celebration rule for marriage formalities (such as which officials are entitled to perform a wedding, how many witnesses are required, and the like) while applying domicillary law to determine the substantive right to marry. This distinction is easily defended on grounds similar to the nearly universal rule that a forum's procedures apply even when the parties' substantive rights are governed by another state's law. See 1 RESTATEMENT (SECOND) of CONFLICT OF LAws $\$ 122$ (1971). It is difficult, by way of comparison, to think of a nondiscriminatory justification for adopting a place of celebration rule for opposite-sex couples while applying domiciliary law to same-sex couples. In any event, the issue in each case is whether the state's rule or practice is intended selectively to discriminate in its willingness to recognize another state's law depending on the law's content. This assessment will turn on what the state's conflicts law looked like before a change was made, and on the reasons offered for changing it, and, of course, on the extent to which it actually discriminates in practice. 
to choice of law for marriage cases. At present, these approaches generally are confined to tort and/or contract cases in the states that use them. ${ }^{122}$ They could, however, easily be extended to marriage cases. This would lead, in the ordinary course of things, to nonrecognition of some Hawaiian marriages without the need to invoke public policy. Under conventional interest analysis, for example, the case of a couple from state $X$ who travelled to Hawail to get married is a false conflict, governed by the law of their common domicile.

If so, so be it. For while the application of modem conflicts analysis might lead to nonrecognition of some marriages, it would eliminate the problem of selective discrimination based solely on the disfavored content of another state's law. Hawaii should not be able to dictate marriage law to the rest of the nation, nor can it do so. Unlike the divorce problems that plagued choice of law in the 1940 s and 1950 s, ${ }^{123}$ celebrating a marriage does not produce a judgment or final judicial decree closed to collateral attack. States retain the power to regulate the marriages of domiciliaries according to their own dictates, including the power to adopt choice-of-law rules establishing the circumstances in which another state's law will apply. The only limitation proposed here is that, if a state adopts a choice-of-law practice that recognizes marriages celebrated elsewhere, the rule or approach it uses cannot be designed or selectively manipulated to disfavor particular laws because their content is deemed especially odious. Whether a state refines its traditional rules or adopts some form of modern analysis for marriage cases, the state's courts must apply that approach without basing their decisions on whether or how strongly they disapprove of a particular state's policy. ${ }^{124}$

\section{THE POWER OF CONGRESS}

There is a further complication. Part II argued that states cannot make an exception to their ordinary choice-of-law rules when those rules say to apply Hawaii law just because they dislike Hawaii's policy choices. Anticipating such an argument, opponents of gay and lesbian marriage went to Congress for permission. Congress responded with the Defense of Marriage Act, which

122. See Symeonides, supra note 117, at 193-203.

123. See CRAMTON ET AL., supra note 53, at 474-75.

124. It is, of course, possible to think of cases in which the rule proposed here would either limit or prohibit practices that seem reasonable. An obvious example is the usury cases, in which states enforce usury laws of other states if (and only if) their permissible interest rates do not greatly exceed forum rates Cf. I RESTATEMENT (SECOND) OF CONFLICT OF LAws $\$ 203$ (1971) (describing rules for usury) This does not trouble me much. Like other legal rules, rules of constitutional law incvitably impose costs as well as benefits, and the rule proposed here is no different. On the whole. I have no doubt that the costs-to the values of full faith and credit and to the goals of minimizing parochialism and maximizang tnterstate cooperation-of permitting selective discrimination of the son discussed here far execed the likely benefits from sensible use of the practice in a few instances. For a contrany view, see Linda J Sulberman. Can the Island of Hawaii Bind the World? A Comment on Same-Sex sfarriage and Federalism Values. 16 QUINNIPIAC L. REV. (forthcoming 1997). 
purports to authorize states to do what I just argued the Full Faith and Credit Clause prohibits. ${ }^{125}$ Section 2 of DOMA provides:

No State, territory, or possession of the United States, or Indian tribe, shall be required to give effect to any public act, record, or judicial proceeding of any other State, territory, possession, or tribe respecting a relationship between persons of the same sex that is treated as a marriage under the laws of such other State, territory, possession, or tribe, or a right or claim arising from such relationship. ${ }^{126}$

This is radical stuff. By parroting the language of the Full Faith and Credit Clause, section 2 literally repeals it for same-sex marriage cases. Not only can a state decline to recognize a marriage of its domiciliaries who went to Hawaii for the weekend, but it also can refuse to recognize the marriage of a same-sex couple who left Hawaii after many years of being lawfully married there. Of course, existing law already permits this much (though, for the reasons explained in Part II, it should not). But section 2 goes further and permits one state to ignore another state's laws recognizing same-sex marriages in more troubling circumstances, such as when one spouse dies leaving property in the state. Existing law may allow this too. Existing law does not, however, allow one state to refuse recognition to the final judgment of another state's courts. $^{127}$ DOMA does-it expressly authorizes states to ignore even judgments involving the marital rights or status of a same-sex couple. All bets are off for these people, and no divorce decree, property settlement, or adoption is safe.

Can the national legislature really do this? Congress purported to act under the second half of Article IV, section 1, which says, "And the Congress may by general Laws prescribe the Manner in which such Acts, Records and Proceedings shall be proved, and the Effect thereof." ${ }^{128}$ For those who like

125. In addition to relieving states of the obligation to give faith and credit in samc-sex marriage cases, DOMA defines marriage for purposes of federal law (including eligibility for federal benefits programs) as "a legal union between one man and one woman." Defense of Marriage Act, Pub. L. No. 104199, § 3(a), 1996 U.S.C.C.A.N. (110 Stat.) 2419,2419 (to be codified at 1 U.S.C. $\S 7$ ). This proviston raises some interesting problems in its own right. Most important, it departs from a uniform and longstanding policy of allowing states to define what constitutes a family and, for the first time, creates a federal law of marriage-ironic for a law justified in the name of states' rights. In addition, because state and federal law interact in so many ways, DOMA will make it difficult for states and communities that recognize same-sex marriage to administer their family and tax laws in an even-handed way. See Herma Hill Kay, Same-Sex Marriage in the Conflict of Laws: A Critique of the Proposed "Defense of Marriage Act", in THE CIVIL LAW IN THE 21st CENTURY 902 (1997).

126. Defense of Marriage Act $\S(2)(a)$.

127. See Yarborough v. Yarborough, 290 U.S. 202, 212-13 (1933) (holding that Full Faith and Credit Clause applies to unalterable decrees of alimony for minor child); Fauntleroy v. Lum, 210 U.S. 230, 237 (1908) (holding that Full Faith and Credit Clause applies even when first state court judgment was for claim that could not have been enforced in second state's courts). A very narrow public policy exception, too narrow for same-sex marriages but still unconstitutional in my view, is recognized in 1 RESTATEMENT (SECOND) OF CONFLICT OF LAWS $\$ 103$ (1971).

128. U.S. CoNST. art. IV, $\$ 1$. 
to play with texts, this so-called Effects Clause provides a splendid opportunity for exegetics: What are "general Laws"? Do "Acts, Records and Proceedings" include common law decisions or just statutes? Does the Clause apply only to how laws and judgments are proved, or can Congress prescribe substantive rules as well? Each of these questions has, in fact, produced its fair share of commentary over the years. ${ }^{129}$ There is, however, "a substantial consensus" 130 today that, whatever mysteries remain, the Effects Clause does indeed authorize Congress to make binding choice-of-law rules for the states. ${ }^{131}$ Yet this consensus is confined to Congress's power to enact choiceof-law rules at all. No one has ever found it necessary to ask just how far Congress can go, because Congress has never legislated even a single choiceof-law rule for states. ${ }^{132}$ (Note how extraordinary DOMA is in this light: Congress was content to let the states slug it out on issues like slavery, miscegenation, divorce, and abortion-but this, it seems, goes too far.) We are dealing with a completely open question, one never addressed by any cour or analyzed in depth by any scholar: ${ }^{133}$ Is Congress's power under the Effects

129. See, e.g., Walter Wheeler Cook, The Powers of Congress Under the Full Fauth and Credit Clause, 28 YALE L.J. 421, 432-34 (1919) (arguing that Clause applies to legislatuve acts as well as judgments); Kur H. Nadelmann, Full Fairh and Credis 10 Judgments and Public Acts: A HustoricalAnalytical Reappraisal, 56 Mich. L. Rev. 33, 71-80 (1957) (anguing that Clause is limited to judgments): Ralph U. Whitten, The Consritutional Limitarions on State Choice of Las: Full Fauth and Credu, 12 MEMPHIS ST. U. L. REv. 1, 3 (1981) (arguing that Clause is merely rule of evidenee governung proof of foreign laws and judgments).

130. See Michael H. Gottesman, Draining the Dismal Swamp: The Case for Federal Chotce of Law Statutes, 80 GEO. L.J. 1, 28 (1991).

131. See CURRIE, supra note 62, at 125; Laycock, supra note 25, at 301 The Supreme Court has indicated in dictum that it believes Congress has this power. See Sun Oil Co $v$ Wonman, 486 U S 717. 729 (1988).

132. The rare legislative effors in this area have, for the most pan, been largely confined to specifynng the effects of sister-state judgments. See 28 U.S.C. $\$ \$ 1738,1738$ A. 1738B (1994) in addition. $\$ \S 1731-37$ and $\$ \$ 1739-46$ deal with proof of various sorts of public records. Finally. Congress has occasionally adopted choice-of-law provisions in connection with issues of federal law. See. e g. id \$ $13+60$ b) (dırectung that tort actions against United States be governed by law of place where act or omission occurred); $t d$. $\$ \$$ 1604-05 (defining circumstances in which foreign sovereign is entuled to immunty): 42 U S C. \$\$ 2000 e(f), 2000e-1 (1994) (defining extraterritorial scope of Tille VII) Pnor to DOMIA, however. Congress had never exercised its power under the Effects Clause either to enact a choice-of-law provision for ordinary state law disputes or to relieve states of any obligations imposed on them by the Full Fath and Credit Clause.

133. Paul Freund touched on the issue of limits on Congress's power to presenbe rules for recognizing judgments in his supert article on the process jurisprudence of Chief Justuce Stone See Paul A. Freund. Chief Justice Stone and the Conflict of Laws, 59 HARV. L. REV 1210 (1946) Discussing the Court's opinion in Magnolia Pesroleun Co. v. Hunt, 320 U.S. 430 (1943). which held that Loussiana violated the Full Faith and Credit Clause by awanding supplementary benefits to a worker who had already obtained relief from the Texas Industrial Accident Board. Freund asked "i $w$ ]hether Congress could legislate under the full faith and credit clause to restore the practice adopted by the Lovisiana cours." Freund. supro, at 1229. "[D]oubtful," he concluded, assering without elaboration that "legishation enlarging the compulsory area of full faith and credit" may be permissible. but "legislation withdrawing from the compulsory area what the Court has held is encompassed by the constitutional mandate may stand on a different fooung." Id. at 1229-30. Justice Stevens cited this passage in a footnote of his plurality opinion in Thomas $v$ Washington Gas Light Co., 448 U.S. 261 (1980), observing that

while Congress clearly has the power to increase the measure of fath and credit that a State must accord to the laws or judgments of another State, there is af least some question whether Congress may cut back on the measure of faith and credit required by a decision of this Cour. 
Clause plenary, or does the Full Faith and Credit Clause impose limits that bind Congress as well as the states? For constitutional law aficionados, the question may be put thus: Is Congress's power under the Effects Clause more like its power under the dormant Commerce Clause or the Fourteenth Amendment?

If asked, most commentators today would probably favor the commerce power analogy. ${ }^{134}$ On this view, the Full Faith and Credit Clause imposes certain judicially defined limits on states, analogous to limits imposed under the dormant Commerce Clause. These have the status of federal common law and can thus be displaced by Congress, which has nearly unlimited power under the Effects Clause to prescribe alternative rules. Hence, a state violates the Full Faith and Credit Clause by applying its law without a legitimate interest, and also, if I am right, by refusing to apply another state's law on public policy grounds. If Congress decides differently, however, it has power under the Effects Clause to authorize states to take these otherwise prohibited steps. On this view of Congress's power, then, DOMA is constitutional.

It is certainly possible to construct an argument to support this interpretation of the Effects Clause. Everyone agrees that requiring full faith and credit is supposed to reduce interstate conflict and foster an attitude of friendly cooperation among the states. With these objects in mind, the Supreme Court has defined certain minimal responsibilities that states owe to each other in terms of recognizing and respecting each other's laws. Yet the Court's judgment that these are necessary or desirable obligations could be wrong; they could even be counterproductive, increasing rather than decreasing centrifugal tendencies within the Union. Obviously, no individual state could be trusted to make such a determination. But Congress is in a different position. Not only does it share the Court's national perspective, but its ability to conduct factfinding and gauge the effects of alternative rules is superior to that of the Court. It thus makes sense to read the constitutional text as conferring plenary authority on Congress to be the final arbiter of what full faith and credit

Id. at 273 n.18 (citation omitted); see also Edward S. Corwin, The "Full Faith and Credit" Clause, 81 U. PA. L. REV. 371, 373-74 (1933) (discussing congressional legislation under Clause).

These authorities deal specifically with judgments, which in most contexts receive greater constitutional protection than laws (though, as indicated above, DOMA also raises a judgments issue). The only reference I have found in the literature to the question of limits on Congress's power to regulate full faith and credit to laws is in Nadelmann, supra note 129, at 83. Observing that Congress's addition of the word "full" to 28 U.S.C. $\S 1738$ in 1952 could be read to "narrow down" the statute's command, Nadelmann asserts without explanation that "[t]o the extent that the Full Faith and Credit clause is selfexecuting, any such narrowing down would have to be discarded as in contravention of the command by the Constitution." Id.

134. As no one has yet written on the question, I base this assertion on conversations with colleagues, many of whom were surprised by the suggestion that DOMA was beyond the power of Congress. Michael McConnell has developed the argument to some extent in a letter to the Senate Judiciary Commiltec. See Hearing Before the Senate Comm. on the Judiciary on S. 1740, 104th Cong. 56-58 (1996) (letter from Professor Michael W. McConnell, University of Chicago Law School, to Senator Orrin G. Hatch). 
requires, with power to specify when particular laws should or should not be applied by other states.

There are a number of problems with this interpretation, which I was originally inclined to accept. To begin, the text of the Clause says that full faith and credit shall be given in each state to the laws and judgments of every other state. It does not say that states shall give faith and credit, but rather that faith and credit shall be given-a use of passive voice that makes this a general command rather than one directed solely at state lawmakers. It does not say that only some faith and credit need be given, but rather that the faith and credit given shall be full. This unqualified "full" and mandatory "shall" lose some (though obviously not all) of their meaning if Congress can simply legislate the requirement away or relieve states of whatever obligations the Full Faith and Credit Clause imposes. It may not be impossible to read the Effects Clause as empowering Congress to do just that, but if that is what the drafters meant, they chose a peculiarly roundabout way of saying so. ${ }^{135}$

Given its language, it is more credible to read the Full Faith and Credit Clause as imposing a mandatory requirement of faith and credit (defined by the Supreme Court), with the Effects Clause authorizing Congress to enact whatever national legislation is needed to refine and implement it. Refine and implement, not undermine or abolish-which means that even federal legislation must be tested against, and shown to be consistent with, the core requirements of full faith and credit.

The legislative history, such as it is, tends to support this textual inference. Some evidence is found in the records of the Federal Convention, though the legal relevance of such evidence is doubtful. ${ }^{136}$ A preliminary version of the

135. My research assistant, Sarah Coyne, points out that this pecultanty is more pronounced given the placement of the power to make choice-of-law rules in Article IV, rather than with Congress's other general powers in Article I, Section 8. In terms of structure and placement, the Effocts Clause is thus most closely analogous to Article III's Exceptions Clause, which authorizes Congress to make exceptuons to the Supreme Court's appellate jurisdiction and which most commentators agree gives Congress only limited power. See Andrew Koppelman, Dumb and DOMA: Why the Defense of Mamage Act is Unconstututional 30-31 (Oct. 1996) (unpublished manuscript, on file with author).

136. The tendency to treat the debates in Philadelpha as the best evidence of onginal understanding is puzzling (to say the least). The Convention had no power to enact anything, and the precise course of its deliberations was unknown to those who did. To treat the Framers' expressions behund closed doors as authoritative is like relying on the understanding of the law clerk who drafted an opinion or the speechwriter who wrote the President's State of the Union Address. Evidence from the Federal Convention should matter insofar as its proceedings were made public and played a role in the subsequent debare over ratification. But the Framers were generally pretly good about keeping their pledge of secrecy (with the notorious but relatively harmless exception of Luther Marun), and very liule of the Philadelpha debates leaked. The records of the Federal Convention might also be relevant to help improve our comprehension of how the ratifiers understood the Constitution. particularly to the extent that the Framers anticipated objections that would be raised in the subsequent campaign. But this is a limited use that does not justufy the sort of detailed parsing of early drafts so common in scholarship about the Consutution. Knowing such details undoubtedly affects one's choice among competing interpretations, which is precisely why we ought to ignore them - they were unknown to those whose choices actually made the Constutution law. For a more

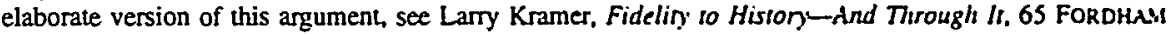
L. REV. 1627, 1642-44 (1997). I have included discussion of the Convention debates on full faith and credit both for general information and for those who find this son of thing more probatuve than I do. 
Full Faith and Credit Clause, introduced by the committee on postponed matters, stated that full faith and credit "ought" to be given to public acts, records, and judicial proceedings of other states, and that Congress "shall" prescribe how these are to be proven and also what effects judgments should have. ${ }^{137}$ When the proposal was taken up for debate, Gouverneur Morris proposed to extend the authority to prescribe effects to everything in the clause, not just judgments. After this passed, Madison moved successfully to substitute "shall" for "ought" in the Full Faith and Credit Clause, and "may" for "shall" in the Effects Clause. ${ }^{138}$ It thus appears that a deliberate decision was made to make the basic requirement of full faith and credit mandatory and to give Congress discretionary power to enforce it.

The Full Faith and Credit Clause received little scrutiny in the campaign for ratification, presumably because it was largely identical to a provision already found in the Articles of Confederation and thus not controversial. ${ }^{139}$ The Effects Clause, however, was new-yet it too received virtually no attention in the debates, which is surprising given the usual eagerness of AntiFederalists to find threats of despotism hiding in every new source of national authority. ${ }^{140}$ The logical inference is that the power granted to Congress was generally understood as authority to implement and facilitate the already familiar requirement of full faith and credit.

This inference is consistent with Madison's elliptical discussion of the power in The Federalist No. 42. Madison commends the Effects Clause as "an evident and valuable improvement on the clause relating to this subject in the articles of confederation," which, he says, is too "indeterminate" to serve any useful purpose. ${ }^{141}$ "The power here established," Madison continues,

may be rendered a very convenient instrument of justice, and be particularly beneficial on the borders of contiguous States, where the effects liable to justice, may be suddenly and secretly translated in any stage of the process, within a foreign jurisdiction. ${ }^{142}$

The problem with the full faith and credit clause of the Articles of Confederation, in other words, was that uncertainty about the nature of the obligation it imposed left room for states to interpret it differently or narrowly

137. See 2 THE RECORDS OF THE FEDERAL CONVENTION OF 1787, at 485 (Max Farrand ed., rev. cd. 1966) (James Madison, Sept. 1, 1787).

138. See id. at 488-89 (James Madison, Sept. 3, 1787).

139. See ARTICLES OF CONFEDERATION art. IV (Aug. 1776) ("Full faith and credit shall be given in each of these states to the records, acts, and judicial proceedings of the courts and magistrates of every other State."). The extension of this obligation in the Constitution to include legislative as well as judicial acts could have provoked a reaction but apparently did not do so.

140. None of the major Anti-Federalist essayists-Cato, Centinel, Federal Farmer, or Brutus-bothered to discuss the Clause. See 2 THE COMPLETE ANTI-FEDERALIST 101-452 (Herbert J. Storing ed., 1981).

141. THE FedERALIST No. 42, at 287 (James Madison) (Jacob E. Cooke ed., 1961).

142. Id. 
(a problem most pronounced near the borders). ${ }^{143}$ The power given to the federal government, Madison explains, enables Congress to give the requirement of full faith and credit a settled, uniform meaning, thus diminishing potential abuses. There is nothing here about needing to relieve states from an obligation that could become too onerous; Madison is describing a power to clarify and enforce, not repeal or diminish.

Although this historical evidence is suggestive, I am reluctant to place much weight on it. To be sure, nothing in the history affirmatively suggests that Congress may relieve states of the obligation to recognize the laws and judgments of sister states, but the evidence against allowing Congress to do so is circumstantial and rests more on what was not said than on what was. Even were the indications of original understanding clearer, moreover, the context in which the problem arises has changed so much in the intervening two centuries that it would be difficult to know just what to do with it. Our conceptual framework has been radically altered since the eighteenth century. Not only was the field of choice of law scarcely in its infancy in America in 1790 , but we have substantially redefined such key concepts as legislative jurisdiction, finality, res judicata, common law, territoriality, sovereignty, and state interests. Further complicating matters, the respective roles of the state and federal governments are vastly different today, as is the nature of interstate relations. Who can say how the Founding generation would have viewed the problem of congressional regulation of faith and credit in the modem context?

This is, of course, a pervasive problem in constitutional law, but most questions have a history subsequent to the Founding that makes interpretation plausible. ${ }^{144}$ What makes the Effects Clause unusual, particularly when it comes to regulating full faith and credit to laws, is that this power has remained untested and practically unexercised for more than two centuries. We do not know for sure what the Founding generation thought, but we also have no intervening experience to help us understand what the Effects Clause has become. The most one can say (and it is saying a lot) is this: Given that the most natural reading of the text and legislative history would limit Congress's power to facilitating and enforcing interstate recognition, Congress's failure ever to exercise the power any other way counsels against its sudden expansion now. The burden, if you will, is on those who urge us to let Congress do something that seems contrary to the language of the Full Faith and Credit Clause, that is inconsistent with what we know of its history, and that Congress has never done in its entire 208-year existence.

143. Although litigation involving questions of faith and credit was rare dunng the Confederauon period, state courts regularly found ways to avoid the obligation. See James D. Sumner, Jr. The Full-Fauhand-Credit Clause-Its History and Purpose, 34 OR. L. REv. 224. 230 (195S).

144. I have developed this argument more fully in Kramer, supra note 136, and Larty Kramer. What's a Constitution for Anyway? Of Histony and Theory, Bruce Ackerman and the New Deal. 46 CASE W. RES. L. REV. 885, 903-33 (1996). 
Against this background, the argument sketched above for allowing Congress to relieve states of their full faith and credit obligations begins to look rather less persuasive. Even apart from textual and historical difficulties, the argument overstates the extent to which the Full Faith and Credit Clause serves merely instrumental ends. We have grown accustomed (perhaps too accustomed) to thinking about structural provisions of the Constitution in strictly utilitarian terms, reserving for rights-bearing provisions the idea that the Constitution also reflects a commitment to principles thought to be intrinsically worthy. Yet the Full Faith and Credit Clause is more than a strategy to minimize friction. It represents the very idea of what it means to be in a Union. States are required to recognize and respect each other's laws because that is what members of a federation do. It may sometimes produce tension, but that inheres in the relationship, less a "cost" than an intrinsic characteristic.

This is a better way to understand and interpret the Full Faith and Credit Clause. Certainly the Founding generation thought of "Union" as more than a handy tool to maximize the interests of member states, and the same ideal runs throughout American history. One need not get dewy-eyed or make soppy references to the Gettysburg Address to see that commitment to Union is itself a fundamental constitutional value. As such, Congress should not be permitted to redefine its terms at will or to legislate away the minimum requirements of mutual respect and recognition it entails any more than Congress can suppress speech or legislate inequality.

This interpretation of the Effects Clause is superior in functional terms as well. For while Congress probably is, as a general matter, better situated than any state to make dispassionate judgments about how best to minimize interstate friction, federal legislators are still subject to plenty of short-term pressures to act badly or for inappropriate reasons. ${ }^{145}$ One way to guard against this is to identify the fundamental elements of full faith and credit and put these beyond the reach of ordinary politics.

Take, for example, one requirement of full faith and credit that everyone accepts: No state may apply its law unless it has a legitimate interest in a controversy. Now imagine that Congress enacted legislation overruling this condition, permitting states with no material contact or connection to a case to apply their laws anyway. Would this be permissible? Should it be? It is theoretically possible, I suppose, that Congress could find some seemingly rational explanation for enacting such legislation. But the likelihood that

145. The suggestion that Congress is better situated to make dispassionate judgments because it is drawn from the whole nation is, of course, the central premise of Madison's famous argument in The Federalist No. 10. When Madison first unveiled the argument in Philadelphia, however, Hamilton scribbled in his notes what has always struck me as a devastating reply: "There is truth in [Madison's proposition]," he wrote, but it does "not conclude so strongly as he supposes-The Assembly when chosen will meet in one room if they are drawn from half the globe-\& will be liable to all the passions of popular assemblies." 1 THE RECORDS OF THE FEDERAL CONVENTION, supra note 137, at 146 (Alexander Hamilton, June 6, 1787). 
Congress would have been prompted to act by this hypothetical rationale, rather than by an inappropriate consideration, seems remote. It makes more sense simply to put the option beyond Congress's reach. The requirement that no state apply its law without a legitimate interest is just too close to the core of full faith and credit to risk congressional misadventure or misbehavior.

Can the same thing be said of the public policy exception? That is, assuming I am right and that states cannot make this exception, should it also be unconstitutional for Congress to do so? On the one hand, it is easier to imagine plausible reasons for Congress to authorize a content-based exception to ordinary choice-of-law rules. On the other hand, given the controversial nature of the issues, the likelihood that Congress will act for improper reasons is also much greater. To put the point bluntly, which of the following explanations seems more plausible: that the members of Congress who supported DOMA did so because they were concerned about interstate friction, or that they did so because they shared the same distaste of same-sex marriage as their state-level compatriots? In light of the tension between the public policy exception and the Full Faith and Credit Clause, this too should be prohibited to Congress.

Such an interpretation still leaves a wide scope for Congress's power under the Effects Clause. Congress may, for example, still enact a comprehensive system of choice of law for the states if it so chooses. Or it can adopt rules to govern a more limited set of issues. In enacting such legislation, however. Congress must respect the same fundamental requirements of full faith and credit as must states-including the requirement that dislike of a particular policy not provide a basis for selective discrimination in deciding when one state must recognize another state's law.

\section{CONCLUSION}

The principal claim of this Article-that the public policy doctrine violates the Full Faith and Credit Clause-may elicit patronizing chuckles from some conflicts scholars. Most of them actually agree that the exception serves no useful purpose, that it has mutated from a rule of jurisdiction reserved for extreme cases into a freewheeling form of unarticulated interest balancing, and that it is a bad idea. But the thought that a doctrine this old and this wellestablished should suddenly turn out to be unconstitutional seems improbable to many.

Apart from a reference to Holmes's famous quip about practices that have been around since the time of Henry IV, ${ }^{146}$ together with a request to reread

146. See O.W. Holmes, The Path of the Law, 10 HaRV. L REv, 457.469 (1897) ("It ts revolung to have no better reason for a rule of law than that so at was land down in the (ume of Henry IV") 
Erie $^{147}$ and Shaffer v. Heitner ${ }^{148}$ (both cases abandoning very old, very well-established rules), I can answer such critics only by reiterating that the public policy exception is at odds with the whole idea of full faith and credit. Faced with a practice that is inconsistent with the purpose underlying a provision of the Constitution, inconsistent with what little precedent exists interpreting that provision, and indefensible as a matter of policy, the mere fact of age begins to look rather less impressive.

I am even more confident that if states cannot selectively discriminate against each other's laws, Congress cannot authorize them to do so. Here we enter completely uncharted territory, with little useful authority for guidance. On balance, however, and much to my surprise because this was not what I thought when I began to write, the better interpretation is that when Congress legislates choice-of-law rules for the states, it must respect the same fundamental limits. The idea of respect and equality implicit in the concept of Union has an irreducible element that even Congress should not be permitted to undo. In my view, this element includes a prohibition against distinctions based on the relative "offensiveness" of a state's otherwise constitutional laws.

147. Erie R.R. v. Tompkins, 304 U.S. 64 (1938).

148. 433 U.S. 186 (1977) (overtuming Pennoyer v. Neff, 95 U.S. 714 (1878)). 